\title{
Inflammatory and cytotoxic effects of bifenthrin in primary microglia and organotypic hippocampal slice cultures
}

\author{
Brahim Gargouri ${ }^{1,25^{*}}$, Nizar M. Yousif ${ }^{1,4}$, Michèle Bouchard ${ }^{3}$, Hamadi Fetoui ${ }^{2}$ and Bernd L. Fiebich ${ }^{1 *}$
}

\begin{abstract}
Background: Pyrethroids, such as bifenthrin (BF), are among the most widely used class of insecticides that pose serious risks to human and wildlife health. Pyrethroids are proposed to affect astrocytic functions and to cause neuron injury in the central nervous system (CNS). Microglia are key cells involved in innate immune responses in the CNS, and microglia activation has been linked to inflammation and neurotoxicity. However, little information is known about the effects of BF-induced toxicity in primary microglial cells as well as in organotypic hippocampal slice cultures (OHSCs).

Methods: Oxidative stress and inflammatory responses induced by BF were evaluated in primary microglial cells and OHSCs incubated with different concentrations of BF (1-20 $\mu \mathrm{M})$ for 4 and $24 \mathrm{~h}$. mRNA and protein synthesis of cyclooxygenase-2 (COX-2), tumor necrosis factor-alpha (TNF-alpha), interleukin-6 (IL-6), nuclear erythroid-2 like factor-2 (Nrf-2), and microsomal prostaglandin synthase-1 (mPGES-1) was also studied by qPCR and Western blot. Cell viability was analyzed by MTT-tetrazolio (MTT) and lactate dehydrogenase (LDH) assays. Neurotoxicity in OHSCs was analyzed by propidium iodide (PI) staining and confocal microscopy.
\end{abstract}

Results: Exposure of microglial cells to BF for $24 \mathrm{~h}$ resulted in a dose-dependent reduction in the number of viable cells. At sub-cytotoxic concentrations, BF increased reactive oxygen species (ROS), TNF-alpha synthesis, and prostaglandin $\mathrm{E}_{2}\left(\mathrm{PGE}_{2}\right)$ production, at both 4- and 24-h time points, respectively. Furthermore, BF incubation decreased superoxide dismutase (SOD), catalase (CAT), and glutathione peroxidase (GPx) activities and increased lipid peroxidation, protein oxidation, and $\mathrm{H}_{2} \mathrm{O}_{2}$ formation. In addition, BF significantly induced protein synthesis and mRNA expression of oxidative and inflammatory mediators after 4 and $24 \mathrm{~h}$, including Nrf-2, COX-2, mPGES-1, and nuclear factor kappaB (NF-kappaB). A 24-h exposure of OHSCs to BF also increased neuronal death compared to untreated controls. Furthermore, depletion of microglia from OHSCs potently enhanced neuronal death induced by BF.

Conclusions: Overall, BF exhibited cytotoxic effects in primary microglial cells, accompanied by the induction of various inflammatory and oxidative stress markers including the Nrf-2/COX-2/mPGES-1/NF-kappaB pathways. Moreover, the study provided evidence that BF induced neuronal death in OHSCs and suggests that microglia exert a protective function against BF toxicity.

Keywords: Bifenthrin, Microglia, Oxidative stress, OHSCs, Nrf-2, NF-kappaB

\footnotetext{
* Correspondence: brahim.gargouri@uniklinik-freiburg.de; bernd.fiebich@uniklinik-freiburg.de

${ }^{1}$ Neuroimmunology and Neurochemistry Research Group, Department of Psychiatry and Psychotherapy, Medical Center - University of Freiburg, Faculty of Medicine, University of Freiburg, Freiburg, Germany

Full list of author information is available at the end of the article
}

(c) The Author(s). 2018 Open Access This article is distributed under the terms of the Creative Commons Attribution 4.0 International License (http://creativecommons.org/licenses/by/4.0/), which permits unrestricted use, distribution, and reproduction in any medium, provided you give appropriate credit to the original author(s) and the source, provide a link to the Creative Commons license, and indicate if changes were made. The Creative Commons Public Domain Dedication waiver (http://creativecommons.org/publicdomain/zero/1.0/) applies to the data made available in this article, unless otherwise stated. 


\section{Background}

Extensive application of pesticides is usually accompanied by serious pollution problems and health hazards. Today, their extensive occupational and domestic use raises many questions about their deleterious health effects [1]. Synthetic pyrethroids (SPs) are among the most commonly used classes of pesticides in agricultural and household formulations and account for one fourth of the total insecticide market worldwide [2-5]. Most importantly, SPs are often classified into two groups based on their chemical structures and neurotoxicological effect. Type I pyrethroids, which lack an alpha-cyano moiety, induce a syndrome consisting of aggressive sparring and fine tremor progressing to whole-body tremor and prostration in rats (T-syndrome). Type II pyrethroids, which contain an alpha-cyano moiety, produce a syndrome that includes pawing, burrowing, salivation, and coarse tremors leading to choreoathetosis in rats (CS-syndrome) $[6,7]$. Although this classification is useful in characterizing these chemicals, a few pyrethroids elicit neurotoxic signs of both syndromes $[6,8,9]$. Furthermore, this classification is based on high-dose effects and may not relate to low-dose effects of SPs $[8,10,11]$.

SPs, including bifenthrin (BF), have been found to induce oxidative stress in animal models resulting in both increased oxidant markers and decreased antioxidant activities [12, 13]. BF is a type I pyrethroid insecticide that can cross the blood-brain barrier $[11,14]$ and induces neurotoxicity by prolonging the opening of voltage-gated sodium channels (VGSC) $[8,15]$. This prolonged opening of $\mathrm{Na}^{+}$channels results in persistent depolarization leading to repetitive firing, and if the exposure is high enough, it can lead to seizures, paralysis, and death [16]. However, recent attention has focused on potential alternative targets that may be involved in pyrethroid toxicity [17]. Specifically, various lines of evidence have suggested possible roles for nuclear erythroid-2 like factor-2 (Nrf-2) and nuclear factor kappaB (NF-kappaB) pathways in the acute manifestation of neurotoxicity and oxidative stress elicited by pyrethroids and some food contaminants such as acrylamide (AA) $[9,18,19]$. In addition, exposure to type I pyrethroids has been shown to induce the release of intracellular $\mathrm{Ca}^{2+}$ and reactive oxygen species (ROS) which can lead to DNA damage and cell death. This cascade involves the activation of NF-kappaBp65, cyclooxygenase-2 (COX-2), microsomal prostaglandin synthase-1 (mPGES-1), and Nrf-2 in the brains of mice and rats [19, 20]. There is also rising evidence that long-term/low-dose SP exposure may have significant neurotoxic effects [21]. In fact, nigrostriatal dopaminergic neurodegeneration has been reported in adult rats following 12 weeks of cypermethrin (CM) exposure [14, 22]. Furthermore, exposure to the type II pyrethroid deltamethrin (DM) was shown to induce apoptosis both in vitro and in vivo in a mouse model [23].

Microglia are macrophage-like resident cells of the CNS [24]. Excessive inflammation involving microglia activation is seen in many neurodegenerative diseases such as Parkinson's disease, Alzheimer's disease (AD), and multiple sclerosis (MS) [25-29]. Upon activation, microglia release inflammatory cytokines and increase the production of inducible nitric oxide synthase (iNOS) and ROS, two oxidative stress markers that have been associated with demyelination and axonal damage in cerebellar cultures [30]. On the other hand, emerging evidence also suggests that activated microglia might act as effectors of processes that promote tissue recovery under pathological conditions [31]. More recently, several pesticides (e.g., permethrin (PM), deltamethrin (DM), and allethrin $(\mathrm{AL}))$ were shown to directly induce the production of inflammatory mediators by microglia [32, 33]. Indeed, inflammatory mediators generated by innate immune CNS cells such as microglia are considered the major culprits in neurodegenerative diseases [34, 35].

Like other cell types, microglia express the Nrf-2 and heme oxygenase-1 (HO-1) systems, which are essential for counteracting oxidative stress and inflammation [36, 37]. Nrf-2-deficient mice are more susceptible to oxidative stress [38] and inflammatory disorders including systemic inflammation [39], localized inflammation, and neuroinflammation [40]. Among the transcription factors regulating inflammation and oxidative stress, NF-kappaB is one of the most relevant factors in microglial cells [41]. Although the neurotoxic potential of $\mathrm{BF}$ has been reported, its impact on microglial cells remains unclear. To our knowledge, studies regarding BF-induced neuroinflammatory and oxidative stress in brain cells such as microglia are lacking. Thus, the aim of the present study was to assess the inflammatory and cytotoxic effects of BF in microglia as well as the neurotoxic effects in OHSCs.

\section{Methods \\ Laboratory animals}

The use of experimental animals was conducted with caution according to the regulations of the Ethics Committee of the University of Freiburg Medical Center and with the official approval from Regierungspräsidium Freiburg (Nr. $\mathrm{X}-13 / 06 \mathrm{~A})$. Animals were obtained from the Center of Experimental Models and Transgenic Services in Freiburg (CEMT-Freiburg). Generally, careful procedures and experimental setup were carried out in this work to minimize animal numbers and their suffering.

\section{Chemicals and reagents}

An analytical standard of BF [2-methylbiphenyl-3-ylmethyl-(Z)-(1RS)-cis-3-(2-chloro-3,3,3-trifluoroprop-1-enyl)-2,2-dimethylcyclopropane carboxylate, 99.5\%] was 
obtained from Sigma-Aldrich (Deissenhofen, Germany). $\mathrm{BF}$ was prepared as a stock solution of $100 \mathrm{mM}$ dissolved in dimethyl sulfoxide (DMSO) and further diluted to appropriate concentrations in culture medium immediately prior to use [42]. 2', $7^{\prime}$-dichlorofluorescein diacetate (DCFH-DA) was obtained from Sigma-Aldrich (Deissenhofen, Germany). Lipopolysaccharide (LPS) from Salmonella typhimurium (Sigma-Aldrich, Deissenhofen, Germany) was resuspended in sterile phosphate-buffered saline (PBS) $(5 \mathrm{mg} / \mathrm{mL})$ as stock and subsequently used at a final concentration of $100 \mathrm{ng} / \mathrm{mL}$. Clodronate disodium salt (Merck Chemicals, Darmstadt, Germany) was prepared as a stock solution of $1 \mathrm{mg} / \mathrm{mL}$ in ultrapure water and stored at $-20{ }^{\circ} \mathrm{C}$. Propidium iodide (PI) dye was obtained from Life technologies (Darmstadt, Germany), prepared as a stock solution of $1 \mathrm{mg} / \mathrm{mL}$ in ultrapure water and stored at $4 \quad{ }^{\circ} \mathrm{C}$. Dulbecco's modified Eagle's medium (DMEM), non-essential amino acids (NEAA), 4-(2-hydroxyethyl)-1-piperazineethanesulfonic acid (HEPES), Hank's balanced salt solution (HBSS), and RPMI-1640 medium were purchased from Life Technologies. Penicillin, streptomycin, and $0.05 \%(w / v)$ trypsin/EDTA were obtained from Sigma-Aldrich. Fetal calf serum (FCS) was purchased from Bio\&Sell (Feucht, Germany). Ethanol 100\% (EthO) was obtained from Sigma-Aldrich (Deissenhofen, Germany). The CellTiter $96^{\circ}$ AQueous One Solution Cell Proliferation Assay kit was obtained from Promega (Mannheim, Germany). EIAs for the determination of prostaglandin $E_{2}$ $\left(\mathrm{PGE}_{2}\right)$ were purchased from Cayman (distributed by Bertin Pharma, Montigny-le-Bretonneux, France) and ELISA kits for rat tumor necrosis factor-alpha (TNF-alpha) from eBioscience, Frankfurt, Germany.

\section{Primary glial cultures}

Primary mixed glial cell cultures were established from the cerebral cortices of 1- to 3-day-old neonatal Sprague Dawley rats as previously described [43, 44]. Cerebral cortices were collected and meninges removed. Forebrains were then minced and gently dissociated by repeated pipetting in Dulbecco's modified Eagle's medium (DMEM) and filtered by passing through a 70- $\mu \mathrm{m}$ nylon cell strainer (BD Biosciences, Heidelberg, Germany). Cells were collected by centrifugation $(1000 \times g, 10 \mathrm{~min})$ and resuspended in DMEM (Life Technologies) containing 10\% fetal calf serum (FCS) (Bio\&Sell) and 1\% penicillin and streptomycin antibiotics (40 and $40 \mu \mathrm{g} / \mathrm{mL}$, respectively). Cells were then cultured on $10-\mathrm{cm}$ cell culture dishes (Falcon, Heidelberg, Germany) with the density of $5 \times 10^{5}$ cells $/ \mathrm{mL}$ in $5 \% \mathrm{CO}_{2}$ at $37^{\circ} \mathrm{C}$. After $12-14$ days in vitro, floating microglia were harvested from mixed glia (astrocyte-microglia) cultures and re-seeded into cell culture plates at the density of $2 \times 10^{5}$ cells/well. On the next day, the medium was removed to get rid of non-adherent cells and fresh medium was added. After $1 \mathrm{~h}$, microglial cells were exposed to different concentrations of BF $(1-20 \mu \mathrm{M})$ for 4 and $24 \mathrm{~h}$; control cells were incubated with the solvent DMSO (0.1\%).

\section{MTT assay and cell viability in primary microglia}

Cell viability was measured by quantitative colorimetric assay with MTT-tetrazolio (MTT), as described previously [45]. Primary microglial cells $\left(3 \times 10^{3}\right.$ cells/well $)$ were seeded on 96-well cell culture plates and incubated for $24 \mathrm{~h}$ in $5 \% \mathrm{CO}_{2}$ at $37^{\circ} \mathrm{C}$ without treatment or treated with different concentrations of BF $(0.1-100 \mu \mathrm{M})$. EthO $100 \%$ and DMSO $10 \%$ were used as positive controls to induce the cell death, thus, serving as positive controls (black columns). After treatment, cells were incubated with $20 \mu \mathrm{L}$ of the CellTiter $96^{\circ}$ AQueous One Solution Cell Proliferation Assay kit (Promega, Mannheim, Germany) for $4 \mathrm{~h}$. Afterwards, supernatants were removed and cells were solubilized with DMSO to detect the intracellular formazan crystals formed in the viable cells. Finally, the absorbance of each well was measured at $490 \mathrm{~nm}$ by using an ELISA reader as described by the manufacturer.

\section{Lactate dehydrogenase measurement in primary microglia}

Membrane integrity was evaluated by measuring lactate dehydrogenase (LDH) in the supernatants of untreated and treated cells. Primary microglial cells $\left(3 \times 10^{3}\right.$ cells per well in 96-well plates) were incubated with different concentrations of $\mathrm{BF}(1-20 \mu \mathrm{M})$ for 4 and $24 \mathrm{~h}$ in $5 \%$ $\mathrm{CO}_{2}$ at $37^{\circ} \mathrm{C}$. Cell culture medium was collected and LDH activity was measured following manufacturer's protocol (Biomagreb, ref. 20012 Ariana, Tunis, Tunisia). The percentage of LDH activity was determined as a percent of enzyme activity in the incubation medium to the total LDH activity. The reduction in absorbance due to NAD $(\mathrm{H})$ oxidation was measured at $340 \mathrm{~nm}$. The absence of the viable cells corresponds to $100 \%$ of $\mathrm{LDH}$ activity in the incubation medium.

\section{Measurement of reactive oxygen species contents in primary microglia}

ROS levels in primary microglial cells were determined using 2,7-dichlorodihydrofluorescein (DCFH-DA). DCFH-DA enters cells passively and is deacetylated by esterase to non-fluorescent DCFH. DCFH reacts with ROS to form DCF, the fluorescent product. Primary microglial cells were seeded into 96-well culture plates $\left(3 \times 10^{3}\right.$ cells/ well) and treated with different concentrations of BF for 4 and $24 \mathrm{~h}$. In brief, $5 \mu \mathrm{M} \mathrm{H_{2 } D C F - D A ~ > w a s ~ a d d e d ~ t o ~}$ each well. The fluorescence was measured every $1 \mathrm{~h}$ during a 4-h time period using a FL800-BioTek spectrofluorometer (Bio-Tek Instruments INC, Germany) with excitation/emission wavelengths of $488 \mathrm{~nm} / 525 \mathrm{~nm}$. 
ROS levels were expressed as the mean percentage of fluorescence absorbance in treated versus control cells.

\section{Determination of prostaglandin $\mathrm{E}_{2}$ and tumor necrosis factor alpha production in primary microglia}

Primary microglial cells were left untreated or incubated with different concentrations of BF $(1-20 \mu \mathrm{M})$ for 4 and $24 \mathrm{~h}$. Afterward, supernatants were collected and then centrifuged at $1000 \times g$ for $5 \mathrm{~min}$ at $4{ }^{\circ} \mathrm{C}$. EIA for $\mathrm{PGE}_{2}$ (Cayman, distributed by Bertin Pharma, Montigny-le-Bretonneux, France) and ELISA for TNF-alpha (eBioscience, Frankfurt, Germany) were performed according to the manufacturer's instructions. For $\mathrm{PGE}_{2}$, standard concentrations of $39-2500 \mathrm{pg} / \mathrm{mL}$ were used and sensitivity of the assay was $36 \mathrm{pg} / \mathrm{mL}$. For TNF-alpha, the standard concentrations were used in the interval of $16-2000 \mathrm{pg} / \mathrm{mL}$ and the detection limit was $16 \mathrm{pg} / \mathrm{mL}$.

\section{Determination of nitric oxide production in primary microglia}

Primary microglial cells $\left(3 \times 10^{3}\right.$ cells/well $)$ were pre-incubated with various concentrations of BF (1-20 $\mu \mathrm{M})$ for 4 and $24 \mathrm{~h}$. After the indicated time points, supernatants were collected and centrifuged at $10,000 \times g$ for $5 \mathrm{~min}$. NO levels in the supernatants were determined using the Griess method [46]. One hundred microliters of supernatants were incubated with $100 \mu \mathrm{L}$ of Griess reagent (Sigma-Aldrich, Deissenhofen, Germany) containing 1\% sulfanilamide, 2\% phosphoric acid, and $0.1 \%$ naphthyethylene diamide. After $20 \mathrm{~min}$ of incubation, absorbance was measured, at $540 \mathrm{~nm}$. Nitrite concentrations in the cells were determined based on a sodium nitrite standard curve. Results were expressed as mean nitrite concentration $(\mu \mathrm{M}) \pm$ SEM for each group.

\section{Measurement of hydrogen peroxide in primary microglia} Primary microglial cells $\left(3 \times 10^{3}\right.$ cells/ well $)$ were left untreated or treated with different concentrations of BF $(1-20 \mu \mathrm{M})$ for 4 and $24 \mathrm{~h}$ in $5 \% \mathrm{CO}_{2}$ at $37{ }^{\circ} \mathrm{C}$. Afterwards, hydrogen peroxide $\left(\mathrm{H}_{2} \mathrm{O}_{2}\right)$ formed by the microglial cells was determined by the ferrous ion oxidation-xylenol orange (FOX1) method [47]. The FOX1 reagent consists of $25 \mathrm{mM}$ sulfuric acid, $250 \mu \mathrm{M}$ ferrous ammonium sulfate, $100 \mu \mathrm{M}$ xylenol orange, and 0.1 M sorbitol. Briefly, $100 \mu \mathrm{L}$ of cell supernatants were added to $900 \mu \mathrm{L}$ of FOX1 reagent, vortexed, and incubated for $30 \mathrm{~min}$ at room temperature. Solutions were then centrifuged at $12,000 \times g$ for $10 \mathrm{~min}$. The amount of $\mathrm{H}_{2} \mathrm{O}_{2}$ in the supernatants was spectrophotometrically determined at $560 \mathrm{~nm}$. Results were expressed as nmol per mg protein.

\section{Determination of lipid peroxidation in primary microglia} Primary microglial cells $\left(3 \times 10^{3}\right.$ cells/ well $)$ were left untreated or treated with different concentrations of BF $(1-20 \mu \mathrm{M})$ and incubated for 4 and $24 \mathrm{~h}$ in $5 \% \mathrm{CO}_{2}$ at
$37{ }^{\circ} \mathrm{C}$. The extent of lipid peroxidation in homogenates of primary microglial cells was then determined by measuring the release of a thiobarbituric acid reactive substance (TBARS) in terms of malondialdehyde (MDA) formation content and was measured using the thiobarbituric acid (TBA) colorimetric assay according to the Draper and Hadley (1990) method [48]. Briefly, cultures were washed with ice-cold PBS, pooled in $0.1 \mathrm{~mol} / \mathrm{L}$ PBS/5\% Triton X-100 buffered solution, and incubated for $1 \mathrm{~h}$ at $37{ }^{\circ} \mathrm{C}$. Then, trichloroacetic acid $(350 \mu \mathrm{l} ; 20 \%$ $w / v)$ was added to $250 \mu \mathrm{L}$ of cellular lysate and centrifuged $\left(1000 \times g\right.$ at $4{ }^{\circ} \mathrm{C}$ for $\left.10 \mathrm{~min}\right)$. Aliquots $(450 \mu \mathrm{L})$ of each supernatant were mixed with an equal volume of $0.5 \%(w / v)$ TBA. The mixture was boiled at $100{ }^{\circ} \mathrm{C}$ for $30 \mathrm{~min}$. After cooling, MDA formation was measured at $520 \mathrm{~nm}$ and results were expressed as $\mathrm{nmol}$ of $\mathrm{MDA} / \mathrm{mg}$ of protein.

Measurements of antioxidant enzyme activities in primary microglia

Microglial cells $\left(3 \times 10^{3}\right.$ cells/well $)$ were plated and treated with different concentrations of BF (1-20 $\mu \mathrm{M})$ for 4 and $24 \mathrm{~h}$ and then collected for the measurement of antioxidant enzyme activities. Catalase (CAT) activity was assayed by the decomposition of hydrogen peroxide according to the method of Aebi et al. [49]. A decrease in absorbance due to $\mathrm{H}_{2} \mathrm{O}_{2}$ degradation was monitored at $240 \mathrm{~nm}$ for $1 \mathrm{~min}$, and the enzyme activity was expressed as nmol $\mathrm{H}_{2} \mathrm{O}_{2}$ consumed/min/mg protein. Superoxide dismutase (SOD) (MnSOD and $\mathrm{Cu} / \mathrm{ZnSOD}$ ) activities were evaluated by measuring the inhibition of pyrogallol activity as described by Marklund et al. [50]. This method is based on the competition between pyrogallol oxidation by superoxide radicals and superoxide dismutation by SOD. The specific $\mathrm{Cu} / \mathrm{Zn}$-SOD inhibition by potassium cyanide allows the Mn-SOD determination in the same conditions. Assays were monitored by spectrophotometry at $420 \mathrm{~nm}$. One unit (U) corresponds to the enzyme activity required to inhibit half of pyrogallol oxidation. SOD activity was expressed as U/mg protein. Glutathione peroxidase (GPx) activity was measured according to Flohe and Gunzleret al. [51]. The enzyme activity was expressed as nmol of GSH oxidized/min/mg protein.

\section{Quantification of mRNA expression by real-time RT-PCR} Primary microglial cells were treated with BF $(1-20 \mu \mathrm{M})$ for 4 and $24 \mathrm{~h}$. Microglia RNA was then isolated using the Qiagen RNeasy Mini kit according to the manufacturer's instructions (Qiagen, Germany), and cDNA was synthesized from $500 \mathrm{ng}$ of total RNA using MMLV reverse transcriptase and random hexamers (Promega, Mannheim, Germany). The synthesized cDNA was used as template for the real-time qPCR amplification carried 
out by the CFX96 real-time PCR detection system using iQ $^{\text {ta }}$ SYBR supermix (LifeTechnologies, Darmstadt, Germany). Specific primer sequences were designed by using the Universal ProbeLibrary (Roche) and were obtained from Biomers (Ulm, Germany). These include primers for Nrf-2, NF-kappaBp65, TNF-alpha, COX-2, mPGES-1, and IL-6 (Table 1). Glyceraldehyde 3-phosphate dehydrogenase (GAPDH) served as an internal control for sample normalization, and the comparative cycle threshold Ct method was used for data quantification as described previously [52].

\section{Western blot analysis}

Primary microglial cells were treated with $\mathrm{BF}$ and then incubated for 4 and $24 \mathrm{~h}$ with or without LPS $(100 \mathrm{ng} / \mathrm{mL})$, which was used as a positive control (black column). Cells were then washed with PBS and lysed in $1.3 \times$ sodium dodecyl sulfate (SDS) containing sample buffer without dithiothreitol (DTT). Protein concentrations were measured using the bicinchoninic acid (BCA) assay (Thermo Fischer Scientific, Waltham, MA). The optical density was read at $570 \mathrm{~nm}$ using a microplate reader, and concentrations were given based on the bovine serum albumin (BSA) protein standard curve. Immediately before electrophoresis, bromophenol blue and DTT (final concentration of $10 \mathrm{mM}$ each) were added to the samples and $30 \mu \mathrm{g}$ of protein from each sample were subjected to SDS-PAGE (polyacrylamide gel electrophoresis) on a $12 \%$ gel under reducing conditions. Proteins were then transferred onto a polyvinylidene fluoride (PVDF) membrane (Merck Chemicals, Schwalbach, Germany) by semi-dry blotting. The membrane was blocked for 1 or $2 \mathrm{~h}$ at room temperature using Rotiblock (Roth, Karlsruhe, Germany) for COX-2 or 5\% blocking milk (BioRad, München, Germany) for the other proteins. Primary antibodies used were anti-COX-2 (1:500; Santa Cruz Biotechnology, Heidelberg, Germany), anti-mPGES-1 (1:6000; Agrisera, Vännas, Sweden), anti-Nrf-2 (1:1000; Santa Cruz Biotechnology), anti-beta-actin (1:5000, Sigma-Aldrich), and anti-NF-kappaB-p65 (1:1000; Santa Cruz Biotechnology). Primary antibodies were diluted in TBS-T and 1\% BSA. Membranes were incubated with the primary antibody overnight at $4{ }^{\circ} \mathrm{C}$, followed by extensive washing (three times for $15 \mathrm{~min}$ each in TBS containing $0.1 \%$ Tween 20 ). Proteins were detected by a 1-h incubation with horseradish peroxidase (HRP)-coupled rabbit anti-goat IgG (Santa Cruz, 1:100000), anti-Mouse IgG (GE Healthcare, 1:20000), or HRP-coupled donkey anti-rabbit (GE Healthcare, 1:25000) using chemiluminescence (ECL) reagents (GE Healthcare). All Western blot experiments were performed at least three times. The densitometric analysis of the Western blots was performed using Image J software $1.47 \mathrm{v}$ (National Institute of Health). The beta-actin signals served as normalization controls for the target proteins.

\section{Preparation of organotypic hippocampal slice cultures}

Organotypic hippocampal slice cultures (OHSCs) were prepared as described earlier $[43,44,53]$ with minor modifications. In brief, slice cultures were prepared from 1- to 3-day-old C57BL/6 wild-type mice under sterile conditions. After decapitation, brains were removed and the hippocampi from both hemispheres were acutely isolated in ice-cold serum-free Hank's balanced salt solution (HBSS), supplemented with $0.5 \%$ glucose (Sigma-Aldrich) and 15 mM HEPES. Isolated hippocampi were cut into 350375- $\mu \mathrm{M}$-thick slices using a tissue chopper (Mcllwain) and were transferred to $0.4 \mu \mathrm{M}$ culture plate inserts (Merck Chemicals, PICM03050). The inserts containing four to six slices were placed in six-well plates containing $1.2 \mathrm{~mL}$ of culture medium per well. Culture medium $(\mathrm{pH} 7.2)$ consisted of $0.5 \times$ minimum essential medium (MEM) containing 25\% heat-inactivated horse serum, 25\% BME basal medium without glutamate, $2 \mathrm{mM}$ glutamax (all from LifeTechnologies), and $0.65 \%$ glucose (Sigma-Aldrich). The slice cultures were kept at $37{ }^{\circ} \mathrm{C}$ in a humidified atmosphere $\left(5 \% \mathrm{CO}_{2}\right)$, and the culture medium was refreshed the first day after preparation and every consecutive 2 days.

\section{Depletion of microglia from slice cultures}

To deplete microglia from OHSCs, slice cultures were placed immediately after preparation either on culture

Table 1 Primer sequences for real-time PCR

\begin{tabular}{lll}
\hline Gene & Primer sequences & \\
\cline { 2 - 3 } name & Forward & Reverse \\
\hline Nrf-2 & 5'-CAGCACATCCAGACAGACACCA-3' & 5'CGTATTAAGACACTGTAACTCGGGAATGG-3' \\
NF-kBp65 & 5'-CTGTTTCCCCTCATCTTTCCCTC-3' & 5'- TCCCGTGTAGCCATTGATCTTG-3' \\
COX-2 & 5'-ATG CTC TTCCGAGCTGTGCT-3' & 5'- CATGGGAGTTGGGCAGTCAT-3' \\
mPGES-1 & 5'-ATGACTTCCCTGGGTTGGGGATGGAG-3' & 5'-TCACAGATGGTGGG CCACTTCCCAGA-3 \\
TNF-alpha & 5'-GTTCTATGGCCCAGACTGA-'3 & 5'-GTGGGTGAGGAGCACGTAGT-'3 \\
IL-6 & 5'-AGTTGCCTTCTTGGGACTGA-'3 & 5'-TTCTGCAAGTGCATCATCGT-'3 \\
GAPDH & 5'-ACCACAGTCCATGCCATCAC-3' & 5'-TCCACCACCCTGTTG CTGTA-3' \\
\hline
\end{tabular}


medium containing clodronate encapsulated in liposomes (Chlodronate Liposomes, Haarlem, Netherlands) or culture medium containing $100 \mu \mathrm{g} / \mathrm{mL}$ clodronate disodium salt (Merck Chemicals, Darmstadt, Germany) $[43,44]$. Twenty-four hours after preparation, the slice cultures were washed briefly with prewarmed PBS and reincubated in fresh culture medium for 7 days before use. The OHSC culture medium was changed every second day.

\section{Immunostaining of organotypic hippocampal cultures}

For immunohistochemical analysis, controls and BF-challenged slice cultures were shortly rinsed in PBS and fixed with $4 \%$ paraformaldehyde (PFA) overnight at $4{ }^{\circ} \mathrm{C}$. After fixation, the slice cultures were rinsed in $\mathrm{PBS}$ and pre-incubated with 5\% normal goat serum (NGS, Vector) in PBS containing 0.3\% Triton $\mathrm{X}-100$ (PBS+) overnight. Subsequently, the slice cultures were incubated with the appropriate primary antibodies overnight in $1 \% \mathrm{NGS} / \mathrm{PBS}+$ at $4{ }^{\circ} \mathrm{C}$. The following primary antibodies were used: rabbit-anti-Iba-1 (1:1000, Wako 019-19741) for detection of microglia, mouse-anti-GFAP (1:600, Chemicon MAB3402) for detection of astrocytes, and mouse-anti-NeuN (1:1000, Chemicon MAB377) for detection of neuronal nuclei. The secondary antibodies used were a donkey-anti-mouse-Alexa488 (Molecular Probes) for NeuN, donkey-anti-rabbit-Alexa633 (Molecular Probes) for Iba-1, and goat-anti-mouse-Cy3 (Jackson IR Laboratories) for GFAP. Imaging was carried out using laser scanning ZEISS LSM 510 META microscope. To quantify neuronal cell death in response to BF-induced neurotoxicity, slice cultures were incubated with $2 \mu \mathrm{g} / \mathrm{mL}$ PI during and after the BF challenge [44, 54]. Immunofluorescently stained OHSCs were analyzed by confocal laser scanning microscopy using a ZEISS LSM 510 META upright microscope (objective, $\mathrm{C}$-apochromat $\times 10$ ), and the number of PI-positive cells were quantified using ImageJ software (as described in [54]). The percentage of cell death was determined by calculation of PI area fraction as a percentage of NeuN area fraction. Quantifications of Iba-1 and GFAP area fractions after BF treatment were calculated as a percentage of untreated control area fraction using ImageJ software $[54,55]$.

\section{Statistical analysis}

All statistical analyses were carried out using GraphPad Prism 6.0 for Windows (GraphPad Software, San Diego, CA). Results were expressed as mean \pm standard errors (mean \pm SEM). Multiple comparisons data were analyzed using one-way ANOVA followed by post hoc StudentNewman-Keuls test. Two-way ANOVA with Bonferroni post hoc test was used for grouped analyses. For each experiment, a $p$ value $<0.05$ was considered statistically significant.

\section{Results}

BF-induced cytotoxicity in primary microglia

The cytotoxicity of BF on primary microglia was assessed using MTT assay (Fig. 1). Microglial cells were left untreated or exposed to various concentrations $(0.1-100 \mu \mathrm{M})$ of BF for $24 \mathrm{~h}$. Furthermore, ethanol (100\%) and DMSO (10\%) were used as positive controls to induce cell death. Exposure to high concentrations $(10-100 \mu \mathrm{M})$ of $\mathrm{BF}$ for $24 \mathrm{~h}$ induced a significant decrease in the cell viability with maximal effects at $100 \mu \mathrm{M}(p<0.05)$ (Fig. 1). In contrast, no significant cell death was observed at lower concentrations (0.1, 1, and $5 \mu \mathrm{M}$ ) of BF (Fig. 1). The positive control ethanol induced $100 \%$ cell death and DMSO approximately 55\% (Fig. 1, black columns).

\section{Effects of BF on lactate dehydrogenase and reactive oxygen species formation in primary microglia}

Primary microglial cells were chosen to investigate the effect of BF on oxidative stress and inflammatory mediators. In a first step, microglial cells were treated with different concentrations of BF (Fig. 2a-d). Treatment for $4 \mathrm{~h}$ with BF $(1-20 \mu \mathrm{M})$ did not affect LDH activity and ROS production (Fig. 2a, c). In contrast, a significant increase of LDH and ROS production was observed $24 \mathrm{~h}$ after BF treatments at concentrations of $1-20 \mu \mathrm{M}$ and 10-20 $\mu \mathrm{M}$, respectively (Fig. 2b, d).

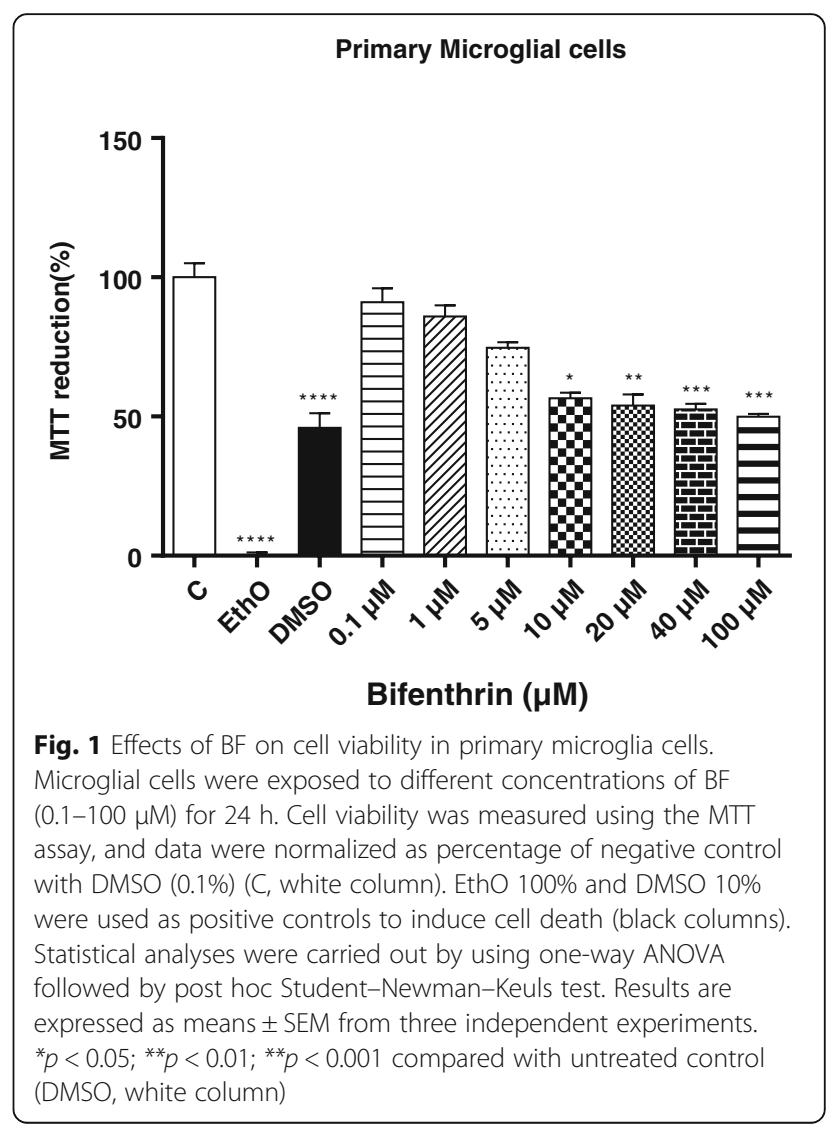



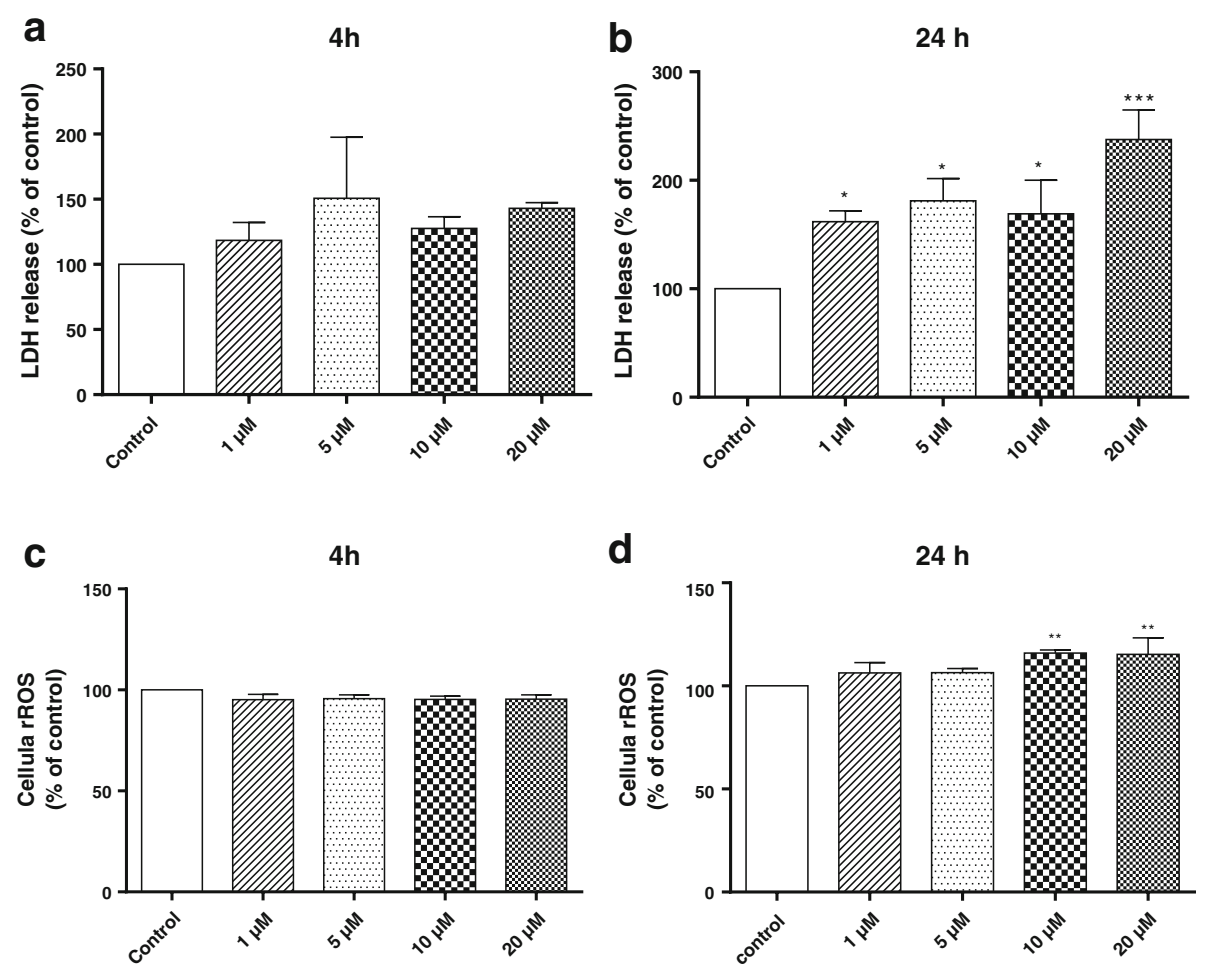

Fig. 2 Effects of BF on lactate dehydrogenase and reactive oxygen species formation in primary microglia. Microglial cells were exposed to different concentrations of BF (1-20 $\mu \mathrm{M})$ for 4 and $24 \mathrm{~h}$. Release of LDH $(\mathbf{a}, \mathbf{b})$ and formation of ROS $(\mathbf{c}, \mathbf{d})$ were measured by a spectrofluorometer. Statistical analyses were carried out by using post hoc Student-Newman-Keuls test. Results are expressed as means \pm SEM of three independent experiments. ${ }^{*} p<0.05 ;{ }^{* *} p<0.01 ;{ }^{*} p<0.001$ compared with control (DMSO, white column)

Effects of BF on prostaglandin $E_{2}$, nitric oxide, and tumor necrosis factor-alpha production in primary microglia To further investigate the direct effects of BF on neuroinflammatory mediators, primary microglial cells were exposed to different concentrations of $\operatorname{BF}(1,5,10$, and $20 \mu \mathrm{M}$ ) for 4 and $24 \mathrm{~h}$ and levels of $\mathrm{PGE}_{2}, \mathrm{NO}$, and TNF-alpha were determined in the cell supernatants (Fig. 3). Our data showed that incubation with BF for $24 \mathrm{~h}$ induced a marked increase in $\mathrm{PGE}_{2}, \mathrm{NO}$, and TNF-alpha production as compared to the vehicle-treated controls, especially at the high concentrations (10-20 $\mu \mathrm{M}$ ) (Fig. 3b, $\mathrm{d}$, and $\mathrm{f}$ ). However, $4 \mathrm{~h}$ after BF treatment, only the highest concentration $(20 \mu \mathrm{M})$ induced $\mathrm{PGE}_{2}$ release and increased NO levels, while TNF-alpha production was not affected (Fig. 3a, c, and e).

\section{Effects of BF on oxidative stress markers in primary microglia}

We next investigated the effects of $\mathrm{BF}$ on two common oxidative stress markers MDA and $\mathrm{H}_{2} \mathrm{O}_{2}$. Our results demonstrate that $24 \mathrm{~h}$ of $\mathrm{BF}$ treatment significantly increased the levels of MDA (at 10-20 $\mu \mathrm{M}$ ) and $\mathrm{H}_{2} \mathrm{O}_{2}$ (at 1-20 $\mathrm{MM}$ ) (Fig. 4b, d). No significant effects were observed following $4 \mathrm{~h}$ of $\mathrm{BF}$ treatment on MDA and $\mathrm{H}_{2} \mathrm{O}_{2}$ levels (Fig. 4a, c).
Effects of BF on enzymatic markers in primary microglia Intracellular levels of antioxidant enzymes, including SOD, CAT, and GPx, were investigated in primary microglial cells incubated with various concentrations of BF $(1,5,10$, and $20 \mu \mathrm{M})$ at 4 and $24 \mathrm{~h}$ (Fig. 5a-f). Our data demonstrated a decrease in SOD activity only with the high concentrations of BF $(10$ and $20 \mu \mathrm{M})$ at $24 \mathrm{~h}$ (Fig. 5b). GPx activity was significantly decreased only with the highest concentration of BF $(20 \mu \mathrm{M})$ at $24 \mathrm{~h}$ (Fig. 5f). Furthermore, a marked decrease in the activity of CAT by BF was observed at different concentrations $(5,10$, and $20 \mu \mathrm{M})$ after $24 \mathrm{~h}$ of treatment (Fig. $5 \mathrm{~d}$ ). In contrast, no significant decrease in the activities of endogenous antioxidant enzymes (SOD, CAT, and GPx) was observed after $4 \mathrm{~h}$ of BF treatment (Fig. 5a, c, and e).

\section{BF exposure increases the expression of pro-} inflammatory markers in primary microglia.

It was further examined whether BF exposure increased mRNA expression of pro-inflammatory cytokines in primary microglia. Treatment with BF $(1-20 \mu \mathrm{M})$ for 4 and $24 \mathrm{~h}$ increased IL-6 and TNF-alpha mRNA expression in a concentration-dependent manner (Fig. 6a, b; Additional file $1 \mathrm{~A} 1-\mathrm{A}$ and $\mathrm{B}$ ). In addition, BF mediated a significant concentration-dependent increase of COX-2 

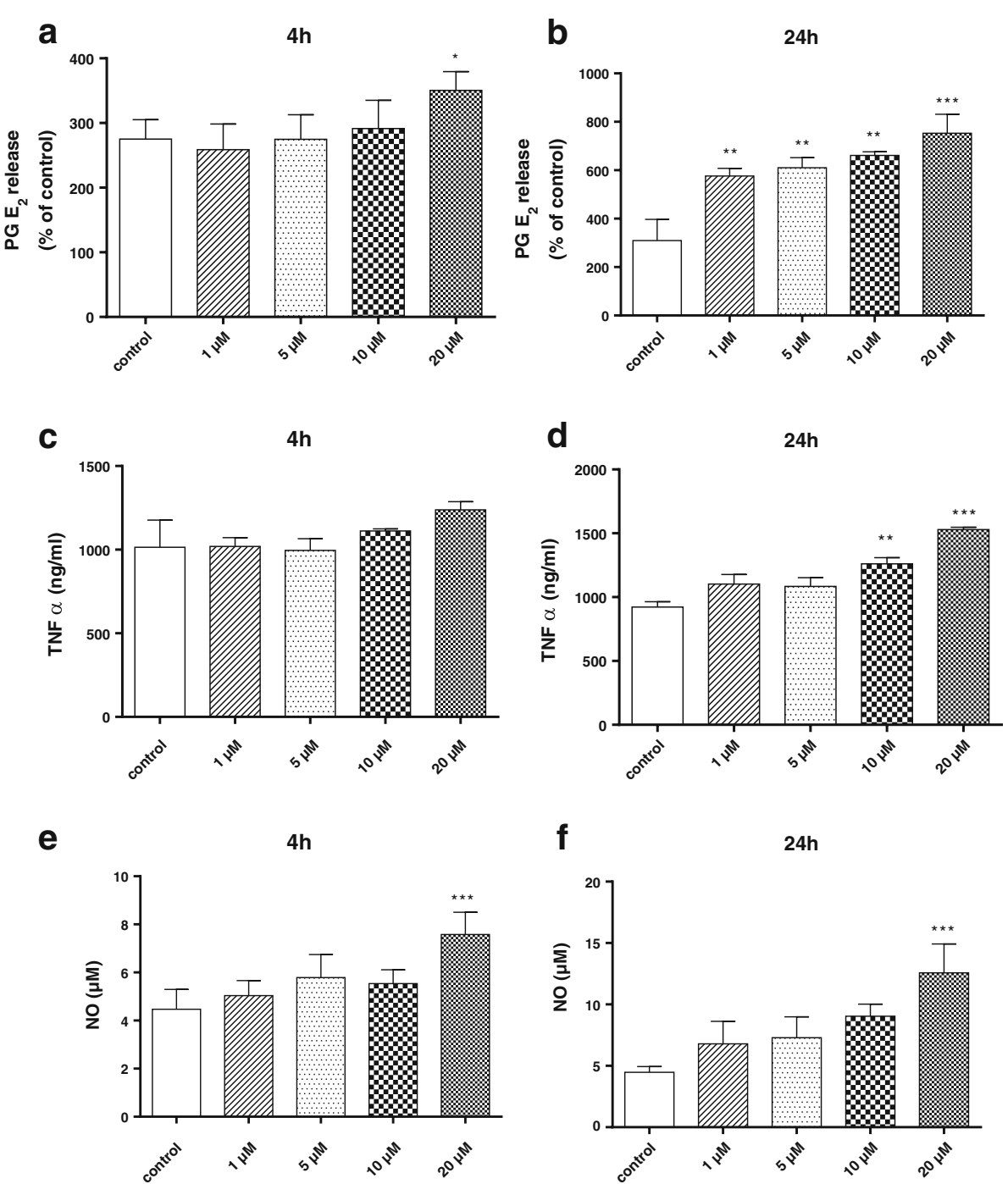

Fig. 3 Effects of $B F$ on prostaglandin $E_{2}$, nitric oxide, and tumor necrosis factor alpha production in primary microglia. Microglial cells were exposed to different concentrations of BF (1-20 $\mu \mathrm{M})$ for 4 and $24 \mathrm{~h}$. At the end of incubation, cell supernatants were collected and the production of $\mathrm{PGE}_{2}(\mathbf{a}, \mathbf{b})$, TNF-alpha $(\mathbf{c}, \mathbf{d})$, and $\mathrm{NO}(\mathbf{e}, \mathbf{f})$ was determined. Statistical analyses were carried out by using one-way ANOVA followed by post hoc Student-Newman-Keuls test. Results are expressed as means \pm SEM of three independent experiments. ${ }^{*} p<0.05 ;{ }^{* *} p<0.01 ;{ }^{* *} p<0.001$ compared with control (DMSO, white column)

and mPGES-1 at the mRNA and protein levels at $24 \mathrm{~h}$ (Fig. 6c-h). After $4 \mathrm{~h}$ of incubation with BF, a marked increase in mRNA and protein levels of COX-2 was observed starting from $5 \mu \mathrm{M}$ (see Additional file 1 A1-C, $\mathrm{E}$, and F). Although a significant increase of mPGES-1 at the mRNA and protein levels was observed with $20 \mu \mathrm{M}$ $\mathrm{BF}$ at $4 \mathrm{~h}$, lower concentrations of $\mathrm{BF}(1-10 \mu \mathrm{M})$ did not exert any effects on this enzyme at the same time point (Additional file 1).

BF exposure increases the expression of Nrf-2 and NF-kappaB in primary microglia

Inflammation and oxidative stress are controlled by several cellular aspects; among them, Nrf-2 and NF-kappaB are the two key transcription factors with a major function in these processes [56]. Therefore, we evaluated the effects of BF on Nrf-2 and NF-kappaB pathways by qPCR and Western blot analysis. We observed a significant increase in mRNA expression of Nrf-2 and NF-kappaBp65 after $24 \mathrm{~h}$ of incubation with $\mathrm{BF}$ in primary microglia (Fig. 7a, b), whereas at $4 \mathrm{~h}$, only NF-kappaBp65 expression was increased (Additional file 2). Increased mRNA expression was detectable starting at $5 \mu \mathrm{M}$ and reached its maximum at $20 \mu \mathrm{M}$ of $\mathrm{BF}$.

Four hours of incubation with BF had no significant effect on the protein level of Nrf-2 (Additional file 2), whereas NF-kappaBp65 protein level was significantly increased by BF starting at $5 \mu \mathrm{M}$ and maximal levels 

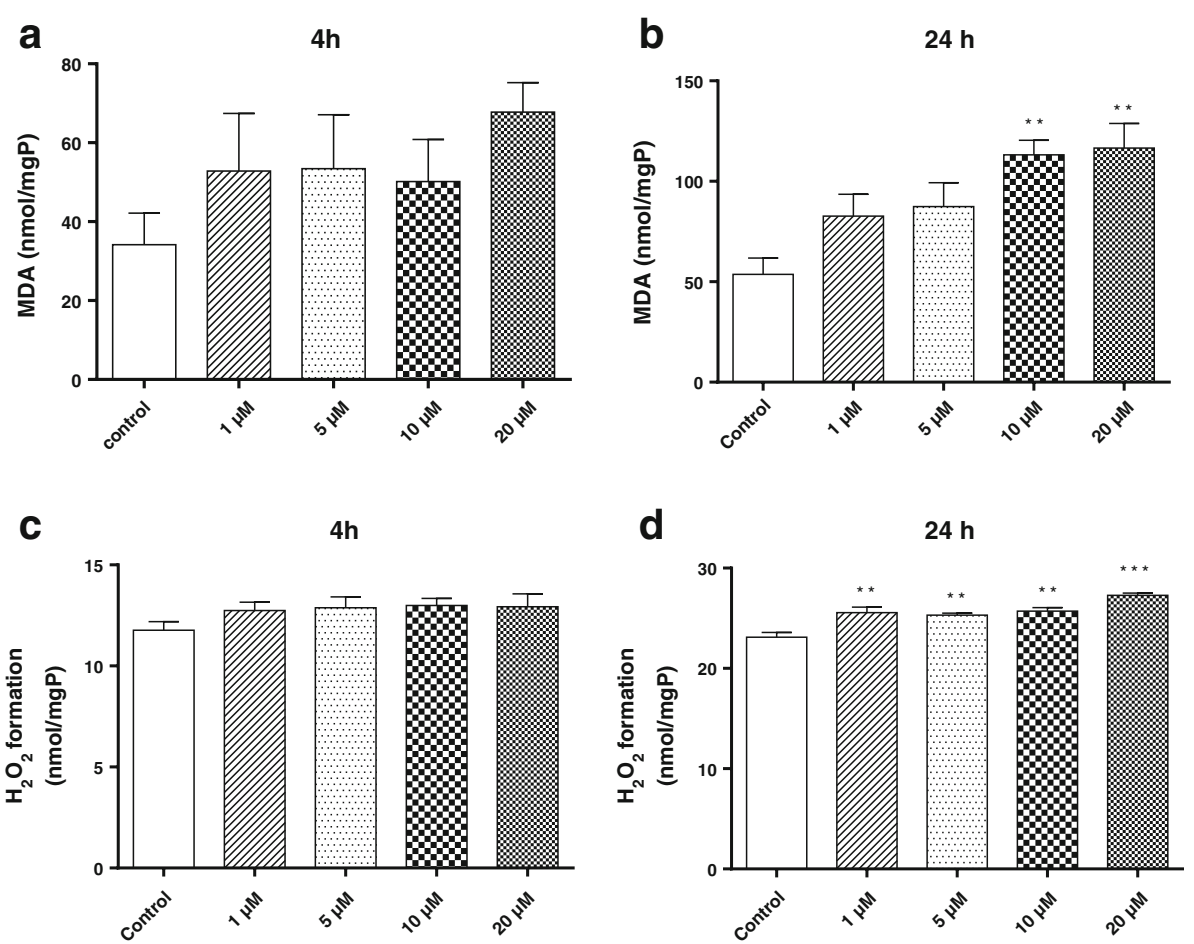

Fig. 4 Effects of BF on oxidative stress markers in primary microglia. Microglial cells were exposed to different concentrations of BF (1-20 $\mu M)$ for 4 and $24 \mathrm{~h}$. Lipid peroxidation (MDA) $(\mathbf{a}, \mathbf{b})$ and hydrogen peroxides $\left(\mathrm{H}_{2} \mathrm{O}_{2}\right)(\mathbf{c}, \mathbf{d})$ levels were measured by a spectrometer. Statistical analyses were carried out by using one-way ANOVA followed by post hoc Student-Newman-Keuls test. Results are expressed as means \pm SEM of three independent experiments. ${ }^{*} p<0.05 ;{ }^{* *} p<0.01 ;{ }^{* *} p<0.001$ compared with control (DMSO, white column)

were identified at $20 \mu \mathrm{M}$ (Additional file 2). Similar to the results obtained from mRNA analysis, Western blot data of the 24-h experiment showed a dose-dependent increase of Nrf-2 and NF-kappaBp65 proteins starting at $5 \mu \mathrm{M}$ of BF (Fig. 7c-f). The highest levels of Nrf-2 and NF-kappaBp65 protein levels were observed at $20 \mu \mathrm{M}$ of BF.

\section{BF-induced neurodegeneration in mouse organotypic hippocampal slice cultures}

To examine possible neurocytotoxic effects of BF ex vivo, we treated OHSCs for $24 \mathrm{~h}$ with $\mathrm{BF}(1-20 \mu \mathrm{M})$ and performed PI and NeuN immunohistochemistry. Confocal images showed that BF treatment at higher concentrations (10 and $20 \mu \mathrm{M}$ ) induced neuronal death (colocalization of PI with NeuN) in all hippocampus layers (CA1, CA3, and DG) with $12 \%(10 \mu \mathrm{M})$ and $31 \%$ $(20 \mu \mathrm{M})$ of PI uptake. However, BF concentrations lower than $10 \mu \mathrm{M}$ did not induce significant cell death in any of the neuronal regions (Fig. 8a, c, and d).

\section{Depletion of microglia enhances neuronal death mediated by $\mathrm{BF}$}

We next aimed to examine whether microglial depletion in OHSCs might affect BF-induced neuronal cell death. We eliminated microglia by clodronate liposomes and subsequently examined neuronal cell death. We recently showed that clodronate treatment successfully depletes microglia without affecting other OHSC cells [44].

OHSCs with and without microglia were treated with different concentrations $(1-20 \mu \mathrm{M})$ of $\mathrm{BF}$ for $24 \mathrm{~h}$. Following microglial depletion, severe neuronal death was observed with all $\mathrm{BF}$ concentrations $(1-20 \mu \mathrm{M})$ as compared to untreated controls and microglia-containing OHSCs (Fig. 8b-d). In microglia-depleted OHSCs, BF induces neurotoxicity even at the low concentrations of $1 \mu \mathrm{M}$ with $13 \%$ and of $5 \mu \mathrm{M}$ with $20 \%$ differences in increased cell death between microglia-depleted and microglia-containing OHSCs, respectively. Cytotoxic effects of BF were severe and further increased at the high concentrations of 10 and $20 \mu \mathrm{M}$ BF in the microglia-depleted OHSCs compared to microglia-containing OHSCs (Fig. 8a-d).

\section{$\mathrm{BF}$ treatment does not induce cell death of microglia and} astrocytes in OHSCs

Confocal images of Iba-1 staining showed no visible differences between BF treatments and controls in microglia (Fig. 9a). In addition, images of the astrocytic marker GFAP demonstrated no changes between $\mathrm{BF}$ treatments and controls (Fig. 9a). Quantifications of GFAP and Iba-1-positive staining area confirmed that $\mathrm{BF}$ does not induce microglial or astrocytic cell death in OHSCs (Fig. 9b, c). 

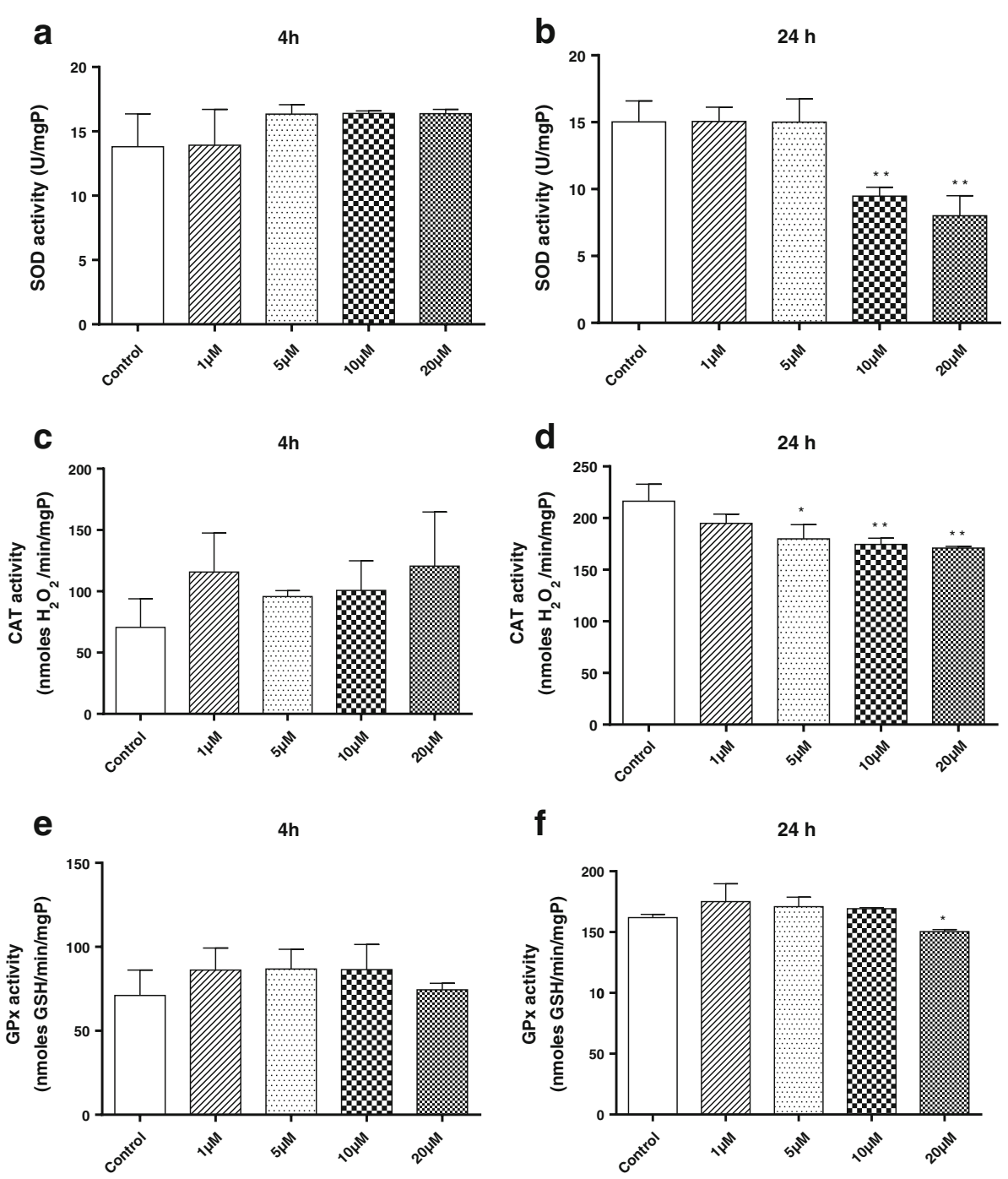

Fig. 5 Effects of BF on enzymatic markers of oxidative stress in primary microglia. Microglial cells were exposed to different concentrations of BF $(1-20 \mu \mathrm{M})$ for 4 and $24 \mathrm{~h}$. Enzyme activities of superoxide dismutase (SOD) (a, b), catalase (CAT) (c, d), and glutathione peroxidase (GPx) (e, f) in primary microglial cells were spectrometrically determined. Statistical analyses were carried out by using one-way ANOVA followed by post hoc Student-Newman-Keuls test. Results are expressed as means \pm SEM of three independent experiments. ${ }^{*} p<0.05 ;{ }^{*} p<0.01 ;{ }^{* *} p<0.001$ compared with control (DMSO, white column)

\section{Discussion}

The effects of pesticides on the brain and the accompanied cellular responses related to these effects are poorly understood [57-60]. Although the toxic responses of pyrethroids in various cell types have been documented and neurotoxic effects of BF are well known, their effects on microglial activation in vitro and neuronal cell death in OHSC ex vivo are not investigated so far in detail $[11,23,61]$.

The main objective of the present study was to characterize the modulatory effects of $\mathrm{BF}$ on microglia-mediated neuroinflammation and neuronal death as a possible consequence and to investigate the neurotoxic impact of BF in OHSCs in the presence or absence of microglia, showing that microglia exert protective functions against BF toxicity. To our knowledge, this is the first study to show cytotoxic effects of BF in microglial cells and in OHSC slice cultures in order to describe possible pathways involved in the oxidative and inflammatory responses related to $\mathrm{BF}$ exposure.

We first examined the hypothesis that BF might induce microglial cytotoxicity. We showed here that BF at concentrations of $10 \mu \mathrm{M}$ or higher caused cytotoxicity, as shown by decreased cell viability levels and increased LDH release. In a similar investigation, it has been shown that DM (type II SP) exposure induces cytotoxicity in SH-SY5Y cells [62]. It has been shown that activated microglia secrete a variety of factors, including 

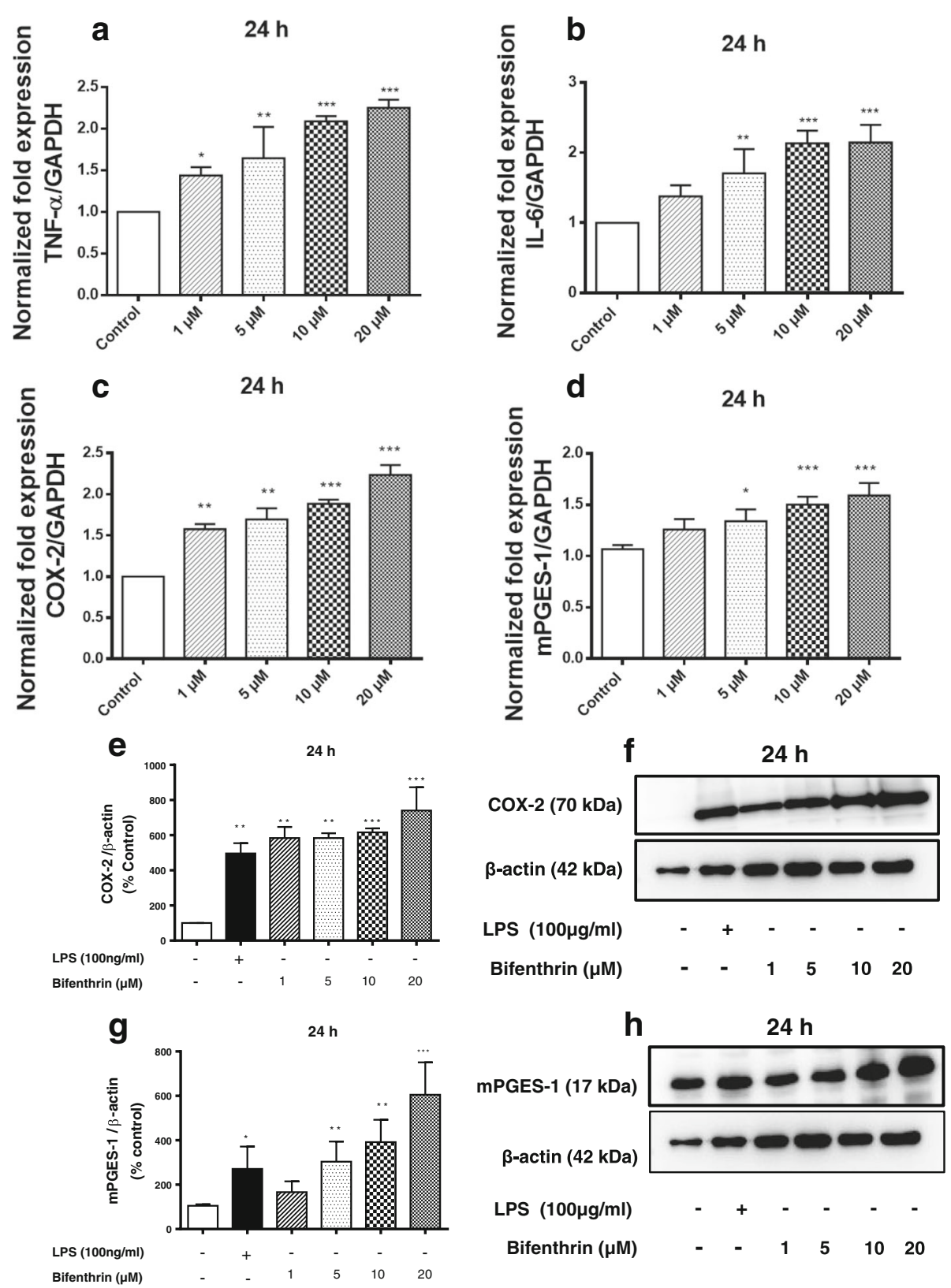

Fig. $6 \mathrm{BF}$ exposure increases the expression of pro-inflammatory markers in primary microglia cells. Microglial cells were exposed to different

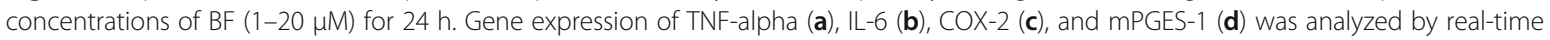
quantitative PCR. GAPDH was used as an internal control for normalization, and data were quantified by using the comparative cycle threshold Ct method. Similarly, cells were treated with BF and thereafter incubated with or without LPS $(100 \mathrm{ng} / \mathrm{mL}$ ) as a positive control (black column) for $24 \mathrm{~h}$. Whole cell lysates were subjected to Western blot for COX-2 (e, $\mathbf{f}), \mathrm{mPGES}-1$ ( $\mathbf{g}, \mathbf{h})$, and beta-actin. To confirm equal sample loading, beta-actin was used for normalization. Data are presented as percentage control of DMSO. Statistical analyses were carried out by using one-way ANOVA followed by post hoc Student-Newman-Keuls test. Results are expressed as means \pm SEM of three independent experiments. ${ }^{*} p<0.05$; ${ }^{* *} p<0.01 ;{ }^{* *} p<0.001$ compared with control (DMSO, white column)

ROS, nitrogen species, cytokines, prostaglandins, and chemokines, which can subsequently results in tissue injury or promote neurotoxicity [63-67]. Furthermore, excessive ROS have serious deleterious effects on cell components, such as lipids, proteins, and DNA, and lead to oxidative stress $[68,69]$. In this study, we demonstrated that BF treatment significantly augments ROS production in primary microglia at different time points. This result was consistent with previous studies on enantioselective oxidative damage to human Hep G2 cells and amnion epithelial cells by BF [70]. 
a

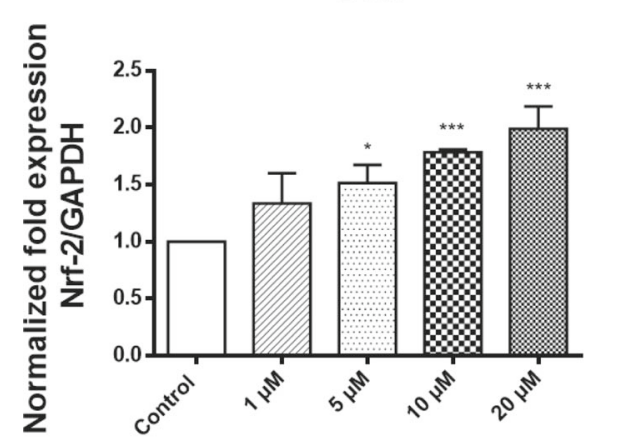

C

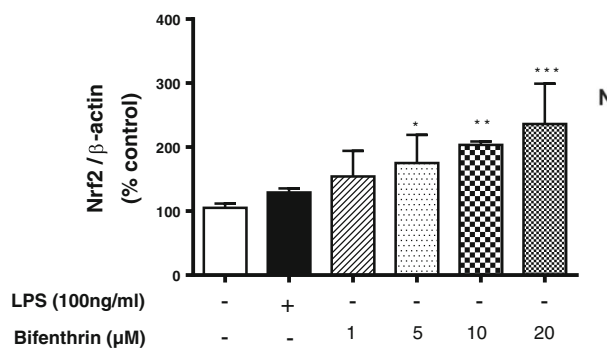

b

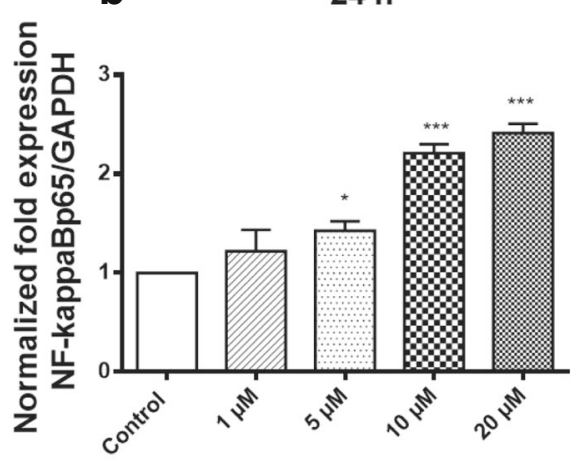

d e

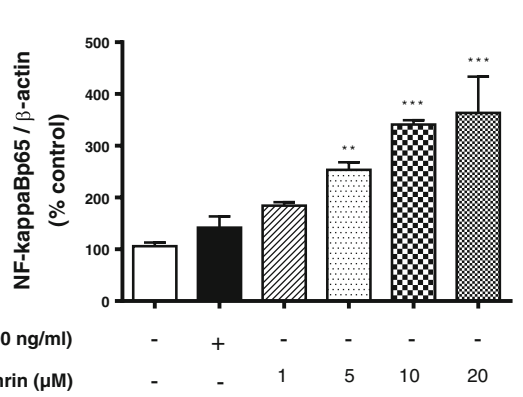

f

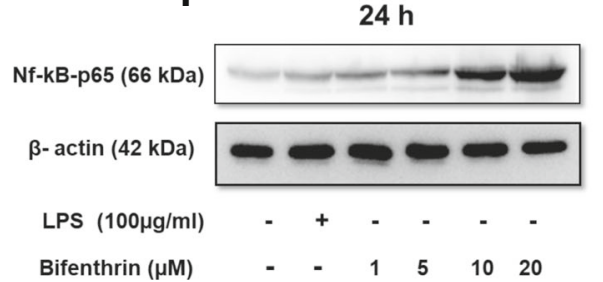

Fig. 7 BF exposure increases the expression of Nrf-2 and NF-kappaB in primary microglia. Microglial cells were exposed to different concentrations of BF (1-20 $\mu \mathrm{M}$ ) for $24 \mathrm{~h}$. Gene expression of Nrf-2 (a) and NF-kappaBp65 (b) was analyzed by real-time quantitative PCR. GAPDH was used as an internal control for normalization, and data were quantified by using the comparative cycle threshold Ct method. Similarly, cells were treated with BF and thereafter incubated with or without LPS (100 ng/mL) as a positive control (black column) for 24 h. Whole cell lysates were subjected to Western blot for Nrf-2 (c, d), NF-kappaBp65 (e, f), and beta-actin. Data are presented as percentage control of DMSO. Statistical analyses were carried out by using one-way ANOVA followed by post hoc Student-Newman-Keuls test. Results are expressed as means \pm SEM of three independent experiments. ${ }^{*} p<0.05$; ${ }^{* *} p<0.01$; ${ }^{* *} p<0.001$ compared with control (DMSO, white column)

Oxidative stress refers to the imbalance between the concentrations of ROS and the antioxidative defense mechanisms of the body [71]. However, many studies showed that pesticides induce oxidative damage and alter the defense system of detoxification and scavenging enzymes [72]. These xenobiotics impair the cellular function and enzyme activity and produce cytotoxic changes through the generation of free radicals. In the present study, BF treatment resulted in a significant decrease in SOD, CAT, and GPx activities in primary microglia, suggesting a BF-induced dysfunction of the antioxidant defense system and confirming the increased production of free radicals caused by the treatment with BF. These findings are similar to those described by El-Demerdash et al. [73], who revealed decreased SOD, CAT, and GPx activities in rat brain exposed to organophosphate and pyrethroid insecticides. Changes in these oxidative stress biomarkers have been reported to be an indicator of the tissue's ability to cope with oxidative 
a

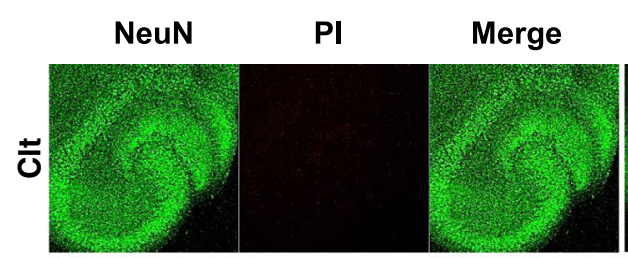

b

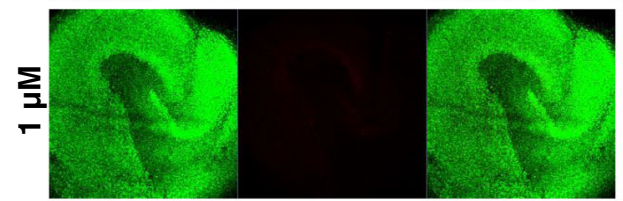

NeuN

PI Merge
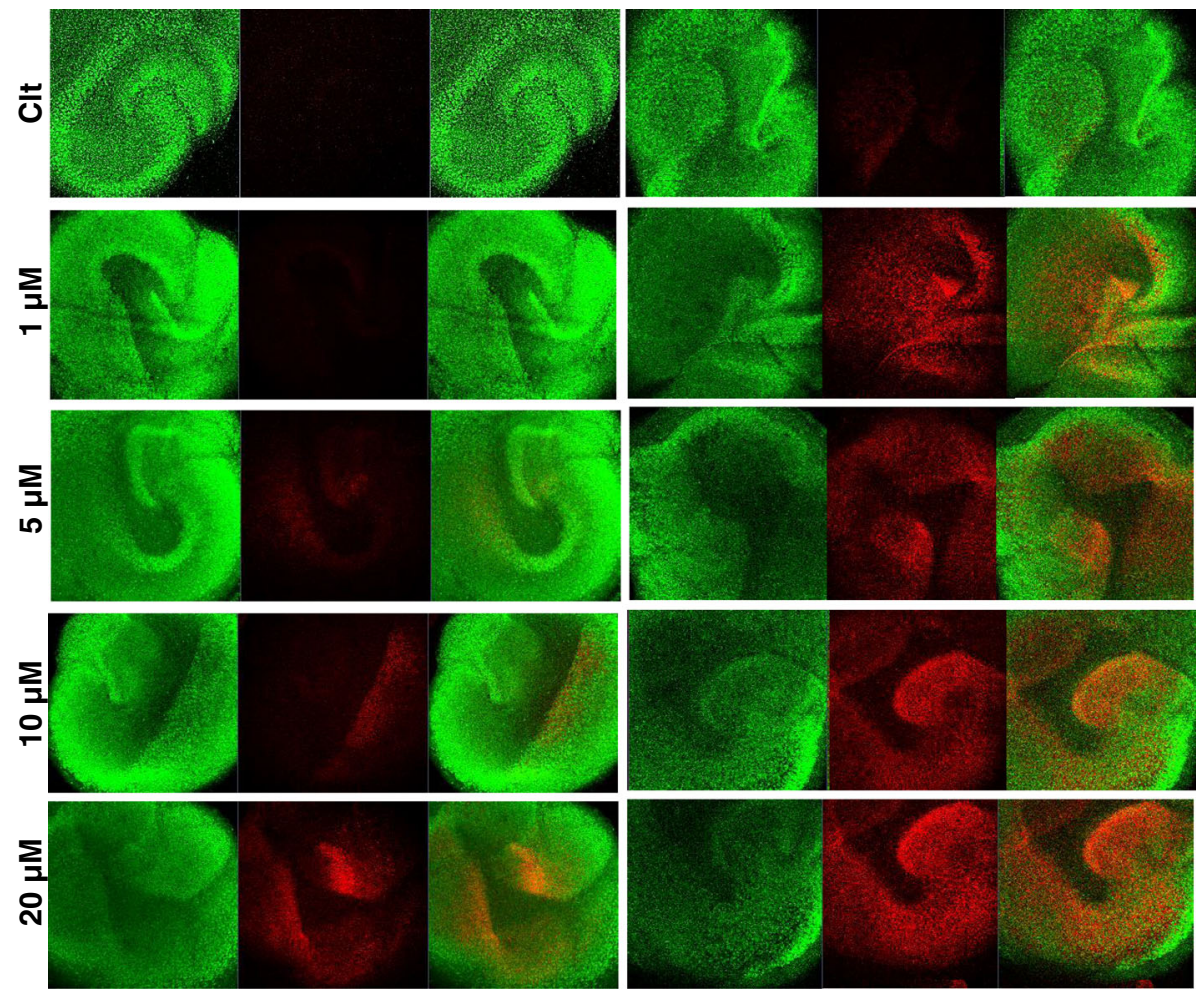

MG

\section{Depleted MG}
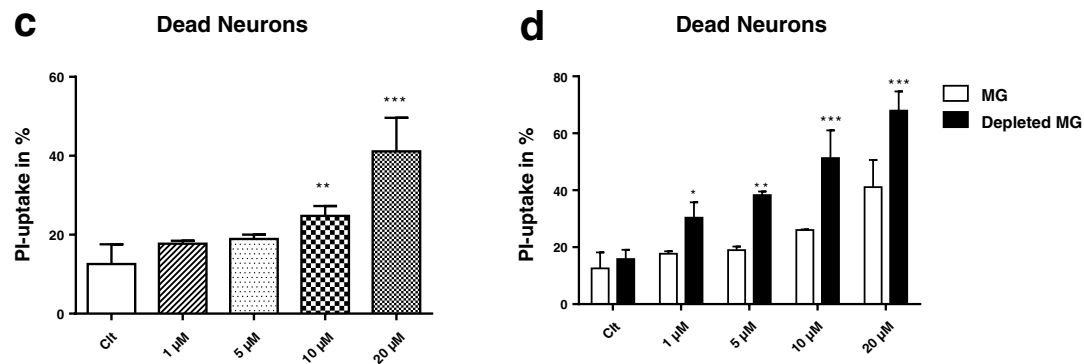

Fig. 8 BF-induced neurodegeneration in mouse organotypic hippocampal slice cultures. After 7 days of incubation in culture, OHSCs were left untreated (control) or treated with different concentrations of BF (1-20 $\mu \mathrm{M})$. Immunolabelling for neuron (NeuN/PI) treatment with BF in microglia-depleted (b-d) and microglia-containing $\operatorname{OHSCS}(\mathbf{a}, \mathbf{c}$, and $\mathbf{d})$, PI (red) is co-localized with the neuronal nuclear marker NeuN (green) (C, white arrow). Data are mean \pm SEM from two independent experiments with six slice cultures/well for each condition. Statistical analyses were carried out by one-way ANOVA followed by post hoc Student-Newman-Keuls test between OHSC treated with different concentrations of BF $(1-20 \mu \mathrm{M})$ and OHSC control group (c), as well as by two-way ANOVA with Bonferroni post hoc test between OHSCs depleted and non-depleted microglia with different concentrations of BF $(1-20 \mu \mathrm{M})$ (grouped analysis) (d). Statistical significance is denoted by ${ }^{*} p<.05,{ }^{* *} p<.01,{ }^{* * *} p<.001$

stress. Additionally, oxidative stress might induce significant lipid and protein peroxidation in cells. As one part of TBARS, MDA was regarded as a marker of lipid oxidation and was the most abundant individual aldehyde resulting from lipid peroxidation [74]. The present study revealed a significant increase in MDA, NO, and $\mathrm{H}_{2} \mathrm{O}_{2}$ levels in BF-treated primary microglia. In similar settings, it was reported that the pesticide PM induced enantioselective oxidative stress in rat PC12 cells in a dose-dependent manner
[75]. This result is consistent with our previous studies in which lambda-cyhalothrin induced oxidative stress and ultimately neuronal damage in rat hippocampus [12].

To counter oxidative stress, microglia, along with other cells of the central nervous system, produce endogenous antioxidants that are regulated predominately through various tightly regulated defense mechanisms to maintain the ROS balance in tissue cells [76-78]. Nrf-2 is a transcription factor that acts as a key regulator of antioxidant-responsive 


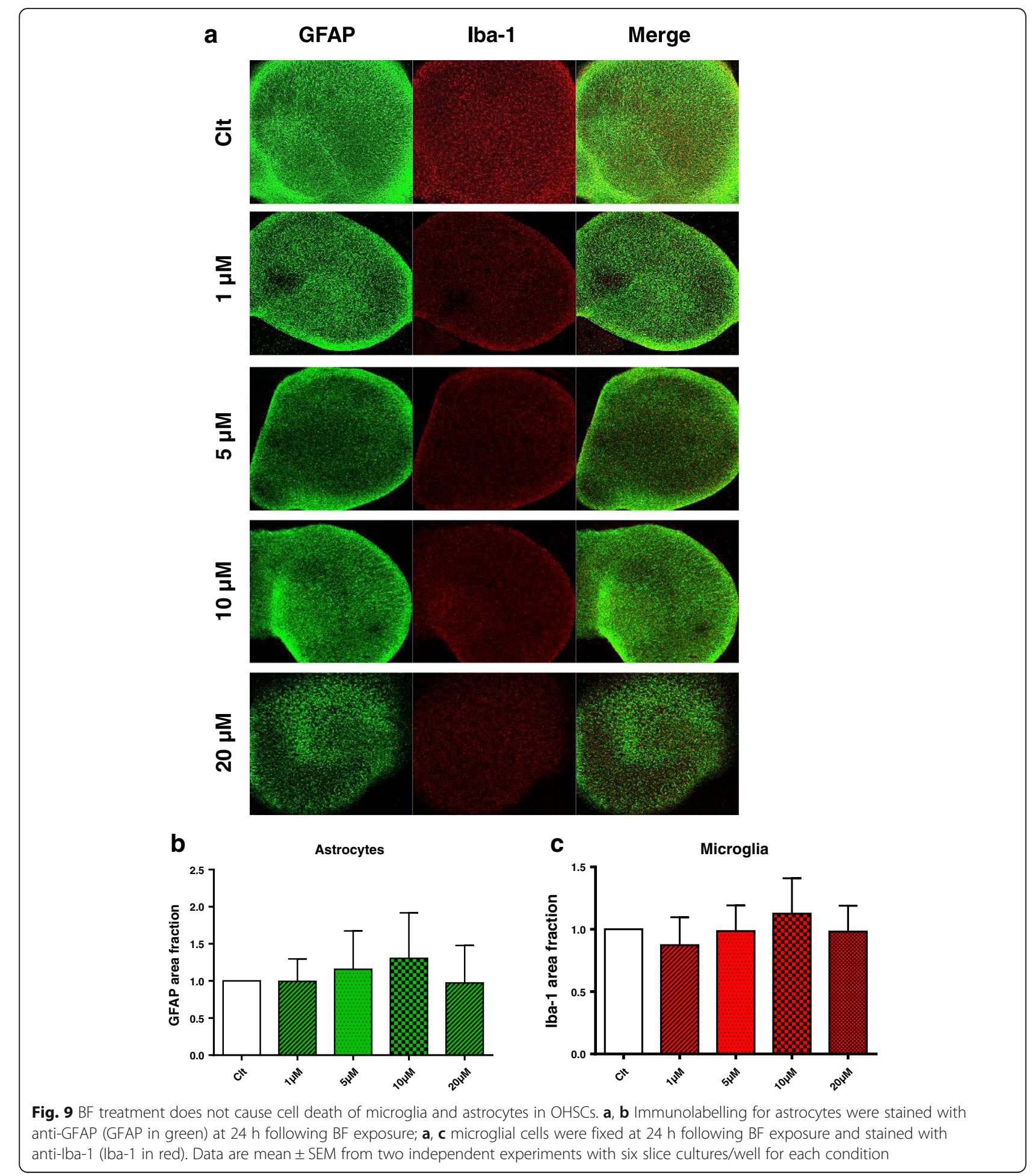

gene such as heme oxygenase 1 (HO-1) and quinone oxidoreductase 1 (NQO1) in tissues and cells and plays a role in acute cerebral lesions and in neurodegenerative disorders [79-81]. Excessive intercellular ROS contribute to Nrf-2 activation to exert protective functions through inducing its target antioxidant genes [82]. In turn, Nrf-2 defense system activation relieves oxidative stress damage by modulating ROS and inflammatory processes [83]. In addition, previous studies have demonstrated that DM, a prototype of widely used pyrethroid pesticides, activates the Nrf-2 pathway in PC12 rat cells [84]. In the current study, we were able to show that $24 \mathrm{~h}$ of exposure to BF increased Nrf-2 
expression and synthesis in primary microglial cells. This finding is particularly important because the progression of cognitive decline and neurodegenerative pathologies is closely associated with increased oxidative stress and microglial activation $[68,85]$. These results are also in line with previous studies $[19,86]$, in which a relationship between AA, DM, and PM exposure in vitro and found increased cellular and nuclear accumulation of Nrf-2 was established, which in turn activated the expression of Nrf-2-regulated oxidative stress response genes. This suggests that the capacity of protection against oxidative damage offered by the Nrf-2-triggered antioxidant proteins may be limited and the system was overwhelmed by the BF exposure.
On the other hand, the neuroinflammatory response during most chronic neurodegenerative diseases is mediated by the activation of glial cells especially primarily microglia [87, 88, 89, 90]. Activated microglial cells produce several inflammatory cytokines such as TNF-alpha, IL-1beta, and IL-6, which are critical in regulating the immune responses in the CNS [55, 91, 92]. However, chronic activation of microglial cells excessively prolongs the inflammatory response and causes neuronal damage, which accelerates the development of neurodegenerative diseases [93, 94]. This response involves the additional production of inflammatory molecules, reactive oxygen species, and other mediators that may lead to detrimental effects [95-97]. NF-kappaB plays a pivotal role in the

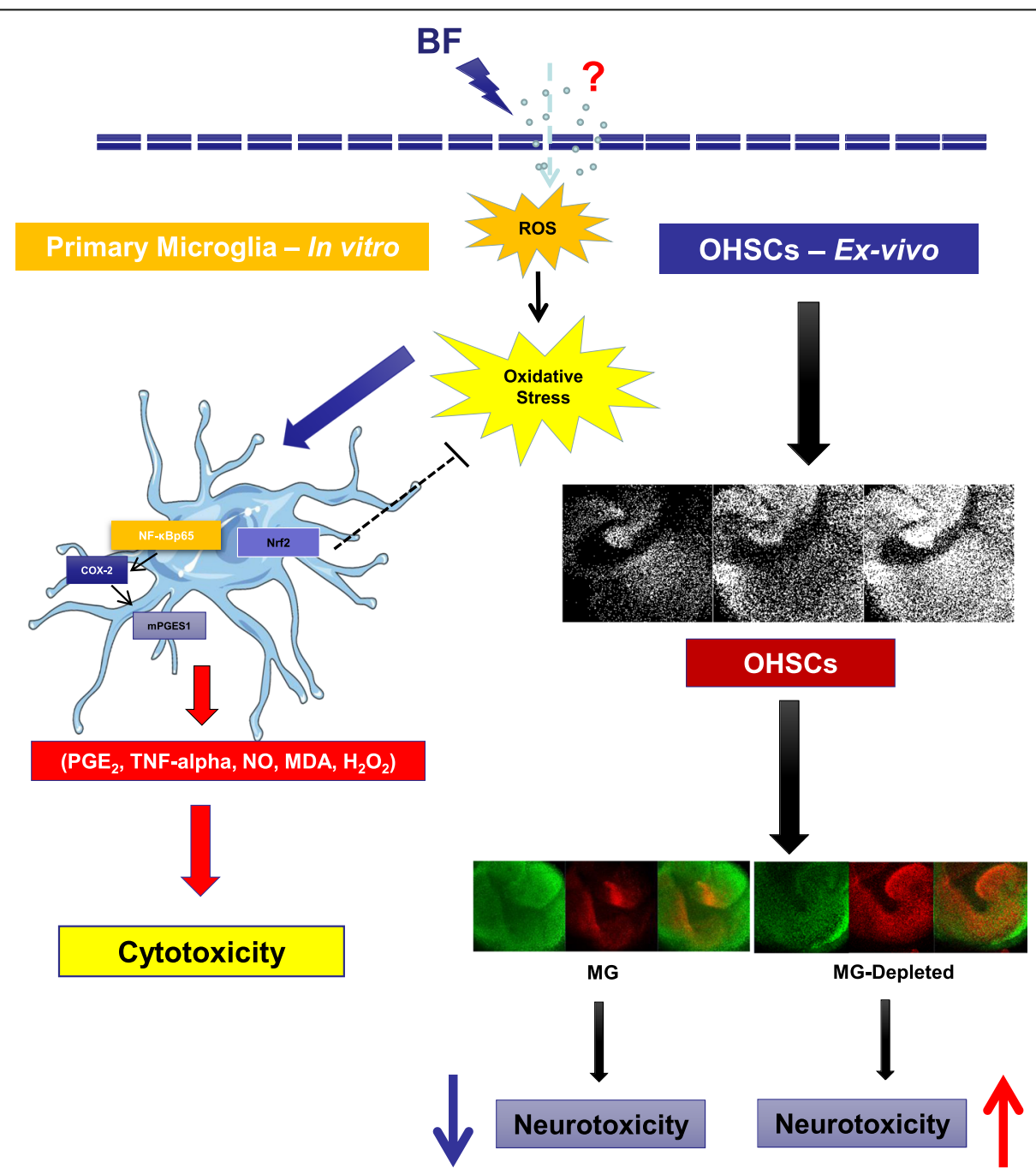

Fig. 10 Schematic representation of BF cytotoxic effects in primary microglia and organotypic hippocampal slice cultures (OHSCs). Effects of exposure to BF in primary microglia on the production of reactive oxygen species (ROS), release of oxidative stress markers (lipid peroxidation $(\mathrm{MDA})$, nitric oxide $(\mathrm{NO})$, hydrogen peroxides $\left(\mathrm{H}_{2} \mathrm{O}_{2}\right)$ and the inflammatory mediators cyclooxygenase-2 (COX-2), microsomal prostaglandin synthase-1 (mPGES-1), prostaglandin E2 ( $\mathrm{PGE}_{2}$ ), and tumor necrosis factor-alpha (TNF-alpha)). Effects of BF on the activation of both nuclear erythroid-2 like factor-2 (Nrf-2) and nuclear factor kappaB (NF-kappaB). (B) Effect of BF treatment on organotypic hippocampal slice cultures (OHSCs - Ex-Vivo) in the presence or absence of microglia (MG) in slice cultures 
regulation of the expression of COX-2 and inflammatory cytokines such as TNF-alpha $[98,99]$. Our current study demonstrated that $\mathrm{BF}$ remarkably increases the expression of NF-kappaB, COX-2, IL-6, and TNF-alpha in microglia, which is associated with increased NO, TNF-alpha, and $\mathrm{PGE}_{2}$ levels in primary microglial cells. Our findings are in agreement with those reported by Zhao et al. [19], who demonstrated that AA significantly increased NF-kappaB and proinflammatory mediators such as IL-1beta, IL-6, and TNF-alpha in astrocytes and microglial cells.

As described in our previous studies, the mPGES-1 and COX-2 enzyme pathway plays a significant role in microglia regulation. mPGES-1 is the terminal enzyme for the biosynthesis of $\mathrm{PGE}_{2}$ during inflammation and is normally functionally coupled with COX-2 with few exceptions $[100$, 101]. The binding of ROS to COX-2 directly elicits its activation, causing overexpression of COX-2 [102]. Our findings demonstrated an increase of COX-2 and mPGES-1 after BF incubation at both mRNA and protein levels.

Wardyn et al. [56] provided compelling evidence that Nrf-2 and NF-kappaB orchestrate the balance of cellular redox status and responses to stress and inflammation. Most importantly, environmental toxin-induced neurotoxicity might be mediated by induction of antioxidant genes through activation of NF-kappaB and Nrf-2 [19, 103-105]. Several lines of evidence suggest that Nrf-2 regulates the inflammatory response by inhibiting pro-inflammatory NF-kappaB activation through maintenance of redox homeostasis. The activation of the NF-kappaB signaling pathway seems to be responsive to excessive ROS generation, thus affecting the redox-sensitive NF-kappaB signaling pathway [106]. However, many pathological and/or physiological stimuli often activate both NF-kappaB and Nrf-2 signaling [107]. Indeed, when PC12 cells are treated for $48 \mathrm{~h}$ with paraquat, a widely used non-selective herbicide, a marked cellular toxic effect accompanied by a sustained ROS generation and NO production was observed [108]. Under these experimental conditions, nuclear protein levels of Nrf-2 and NF-kappaB were both increased, with maximal translocation of NF-kappaB. Our findings suggest that Nrf-2 and NF-kappaB play crucial roles in BF-induced oxidative stress and are further associated with neurotoxicity in primary microglia cells (Fig. 10).

Despite increasing evidence for severe neurotoxic effects of BF, few studies focused on neuronal cell models, whereby microglial cells have been mostly neglected. Immunohistochemical analyses of organotypic hippocampal slice cultures (OHSCs) treated with BF revealed the induction of neuronal cell death. OHSCs are known to preserve many morphological and functional features of the in vivo environment over long periods in culture and have been used in many models of excitotoxicity $[43,54,109,110]$. In our current study, BF treatment of OHSCs resulted in a significant concentration-dependent neuronal cell death in all neuronal layers. Comparable neuronal damage in OHSCs is observed by kainic acid (KA) and N-Methyl-D-aspartic acid (NMDA) [43, 110]. Excitingly, upon microglial depletion, BF induces neurotoxicity even in low concentrations of 1 and $5 \mu \mathrm{M}$, which were not affected in the presence of microglia. Neurotoxic effects of $\mathrm{BF}$ were strongly exaggerated using high concentrations of BF $(10$ and $20 \mu \mathrm{M})$ inducing severe neuronal death if compared to OHSCs containing microglia. This data suggest a neuroprotective function for microglia against BF cytotoxicity. In this context, future investigations should unravel the underlying mechanism beyond this microglia protective effect in OHSCs. This result was consistent with the previous report by Vinet et al. [31], who demonstrated that depletion of microglia resulted in severe neuronal loss following NMDA excitotoxicity. We were able to observe that BF treatment affects neither microglial cells nor astrocyte populations in OHSCs, indicating specific neuronal vulnerability towards BF.

\section{Conclusion}

In conclusion, our findings identified $\mathrm{BF}$ as a potentiator of oxidative stress and inflammatory mediators in primary microglial cells that ultimately contributed to cytotoxicity. Furthermore, we provided evidence that BF promotes neuronal death in OHSCs and found that microglia exert protective function against BF neurotoxicity.

\section{Additional files}

Additional file 1: BF exposure increases the expression of pro-inflammatory markers in primary microglia cells. Microglial cells were exposed to different concentrations of BF for $4 \mathrm{~h}$. Gene expression of TNF-alpha (A), IL-6 (B), COX-2 (C), and mPGES-1 (D) was analyzed by real-time quantitative PCR. GAPDH was used as an internal control for normalization, and data were quantified by using the comparative cycle threshold Ct method. Similarly, cells were treated with BF and thereafter incubated with or without LPS $(100 \mathrm{ng} / \mathrm{mL})$ as a positive control (black column) for $4 \mathrm{~h}$. Whole cell lysates were subjected to Western blot for COX-2 (E and F), mPGES-1 ( $G$ and H), and beta-actin. To confirm equal sample loading, beta-actin was used for normalization. Moreover, data are presented as percentage control of DMSO. Statistical analyses were carried out by using one-way ANOVA followed by post hoc Student-Newman-Keuls test. Results are expressed as means \pm SEM of three independent experiments. ${ }^{*} p<0.05 ;{ }^{* *} p<0.01$; ${ }^{* *} p<0.001$ compared with control (DMSO, white column). (PDF $212 \mathrm{~kb}$ )

Additional file 2: BF exposure increases the expression of $\mathrm{Nrf}-2$ and NF-kappaB in primary microglia. Microglial cells were exposed to different concentrations of BF $(1-20 \mu \mathrm{M})$ for $4 \mathrm{~h}$. Gene expression of Nrf-2 (A) and NF-kappaBp65 (B) was analyzed by real-time quantitative PCR. GAPDH was used as an internal control for normalization, and data were quantified by using the comparative cycle threshold Ct method. Similarly, cells were treated with BF thereafter incubated with or without LPS (100 ng/mL) as a positive control (black column) for $4 \mathrm{~h}$. Whole cell lysates were subjected to Western blot for Nrf-2 (C and D), NF-kappaBp65 (E and F), and beta-actin. Data are presented as percentage control of DMSO. Statistical analyses were carried out by using one-way ANOVA followed by post hoc Student-Newman-Keuls test. Results are expressed as means \pm SEM of three independent experiments. ${ }^{*} p<0.05 ;{ }^{* *} p<0.01 ;{ }^{* *} p<0.001$ compared with control (DMSO, white column). (PDF 258 kb) 


\section{Abbreviations}

AA: Acrylamide; AB: Antibody; AD: Alzheimer's disease; AL: Allethrin; BCA: Bicinchoninic acid; BF: Bifenthrin; BME: Basal Medium Eagle; BSA: Bovine serum albumin; CAT: Catalase; CM: Cypermethrin; CNS: Central nervous system; COX: Cyclooxygenase; DCFH-DA: 2',7'-dichlorofluorescein diacetate; DM: Deltamethrin; DMEM: Dulbecco's modified Eagle's medium; DMSO: Dimethyl sulfoxide; DPBS: Dulbecco's phosphate-buffered saline; DTT: Dithiothreitol; ECL: Chemiluminescence; EthO: Ethanol; FBS: Fetal bovine serum; FCS: Fetal calf serum; FOX1: Ferrous ion oxidation-xylenol orange; GAPDH: Glyceraldehyde 3-phosphate dehydrogenase; GFAP: Glial fibrillary acidic protein; GPx: Glutathione peroxidase; $\mathrm{H}_{2} \mathrm{O}_{2}$ : Hydrogen peroxide; HBSS: Hank's balanced salt solution; HEPES: 4-(2-hydroxyethyl)-1piperazineethanesulfonic acid; HRP: Horseradish peroxidase; Iba-1: Ionized calcium-binding adapter molecule 1; IL: Interleukin; iNOS: Nitric oxide synthase; LDH: Lactate dehydrogenase; LPS: Lipopolysaccharide; MDA: Malondialdehyde; MEM: Minimum Essential Medium; mPGES: Microsomal prostaglandin E synthase; MS: Multiple sclerosis; MTT: MTT-tetrazolio; NEAA: Non-essential amino acids; NF-kappaB: Nuclea factor kappa-light-chain-enhancer of activated B cells; NGS: Normal goat serum; NMDA: N-Methyl-D-aspartic acid; Nrf-2: Nuclear erythroid-2 like factor2; OHSCs: Organotypic hippocampal slice cultures; PBS: Phosphate-buffered saline; PFA: Paraformaldehyde; PG: Prostaglandin; PI: Propidium iodide; PM: Permethrin; PVDF: Polyvinylidene fluoride; ROS: Reactive oxygen species; SDS: Sodium dodecyl sulfate; SDS-PAGE: Sodium dodecyl sulfatepolyacrylamide gel electrophoresis; SOD: Superoxide dismutase; SPs: Synthetic pyrethroids; TBA: Total bile acids; TBARS: Thiobarbituric acid reactive substance; TNF: Tumor necrosis factor; VGSC: Voltage-gated sodium channels

\section{Acknowledgements}

The skillful technical assistance of Ulrike Götzinger-Berger and Brigitte Günter is greatly acknowledged. Brahim Gargouri received a fellowship from BMBF/MESRS (TUNGER-36) and Alzheimer Forschungsinitiative (AFI). Nizar M. Yousif was supported by a scholarship as per the State Law on Graduate Funding (LGFG-IGA, Freiburg). We thank the University of Freiburg Library for their support via the funding program "Open Access Publishing."

\section{Funding}

Brahim Gargouri received fellowships from BMBF/MESRS (TUNGER-36) and Alzheimer Forschungsinitiative (AFI). The project was in part supported by the AIF project GmbH (BMWi) (AGEsense) and BMBF/MESRS (TUNGER-36). Nizar M. Yousif was supported by a scholarship as per the State Law on Graduate Funding (LGFG-IGA, Freiburg). The article processing charge was funded by the University of Freiburg Library in the funding program "Open Access Publishing."

\section{Availability of data and materials}

All data are provided in the manuscript and in the additional files.

\section{Authors' contributions}

$\mathrm{BLF}, \mathrm{BG}, \mathrm{MB}$, and $\mathrm{HF}$ participated in the research design. The experiments were performed by BG and NMY. Data were analyzed by BG, NMY, HF, and BLF. BLF, BG, MB, NMY, and HF contributed to the writing of the manuscript. In addition, BG, HF, NMY, and BLF reviewed the data and discussed the manuscript. All authors have read and approved the final version of the manuscript.

\section{Ethics approval and consent to participate}

All procedures used in this study were approved and performed according to the guidelines of the Ethics Committee of the University of Freiburg Medical School with the official approval from Regierungspräsidium Freiburg (Nr. X-13/06A)

\section{Competing interests}

The authors declare that they have no competing interests.

\section{Publisher's Note}

Springer Nature remains neutral with regard to jurisdictional claims in published maps and institutional affiliations.

\section{Author details}

'Neuroimmunology and Neurochemistry Research Group, Department of Psychiatry and Psychotherapy, Medical Center - University of Freiburg, Faculty of Medicine, University of Freiburg, Freiburg, Germany. ${ }^{2}$ Laboratory of Toxicology-Microbiology and Environmental Health (17ES06), Sciences Faculty of Sfax, University of Sfax, BP1171, 3000 Sfax, Tunisia. ${ }^{3}$ Department of Environmental and Occupational Health, Toxicological Risk Assessment and Management, University of Montreal, Roger-Gaudry Building, U424, Main Station, Montreal, P.O. Box 6128, Montreal, Quebec H3C 3J7, Canada. ${ }^{4}$ Faculty of Biology, University of Freiburg, Freiburg, Germany. ${ }^{5}$ Laboratory of Translational Psychiatry, Department of Psychiatry and Psychotherapy, Medical Center Faculty of Medicine, University of Freiburg, Hauptstrasse 5, 79104 Freiburg, Germany.

Received: 22 January 2018 Accepted: 10 May 2018

Published online: 24 May 2018

\section{References}

1. Thompson LA, Darwish WS, Ikenaka Y, Nakayama SMM, Mizukawa H, Ishizuka M. Organochlorine pesticide contamination of foods in Africa: incidence and public health significance. J Vet Med Sci. 2017;79:751-64.

2. Kale M, Rathore N, John S, Bhatnagar D. Lipid peroxidative damage on pyrethroid exposure and alterations in antioxidant status in rat erythrocytes: a possible involvement of reactive oxygen species. Toxicol Lett. 1999;105:197-205

3. Fetoui $H$, Garoui EM, Makni-ayadi F, Zeghal N. Oxidative stress induced by lambda-cyhalothrin (LTC) in rat erythrocytes and brain: attenuation by vitamin C. Environ Toxicol Pharmacol. 2008;26:225-31.

4. Deziel NC, Friesen MC, Hoppin JA, Hines CJ, Thomas K, Freeman LEB. A review of nonoccupational pathways for pesticide exposure in women living in agricultural areas. Environ Health Perspect. 2015;123:515-24.

5. Narayan S, Sinsheimer JS, Paul KC, Liew Z, Cockburn M, Bronstein JM, et al. Genetic variability in ABCB1, occupational pesticide exposure, and Parkinson's disease. Environ Res. 2015;143:98-106.

6. Aldridge WN, Dinsdale D, Nemery B, Verschoyle RD. Some aspects of the toxicology of trimethyl and triethyl phosphorothioates. Fundam Appl Toxicol Off J Soc Toxicology 1985:5:S47-S60.

7. Lawrence LJ, Casida JE. Pyrethroid toxicology: mouse intracerebral structuretoxicity relationships. Pestic Biochem Physiol. 1982;18:9-14.

8. Soderlund DM, Clark JM, Sheets LP, Mullin LS, Piccirillo VJ, Sargent D, et al. Mechanisms of pyrethroid neurotoxicity: implications for cumulative risk assessment. Toxicology. 2002;171:3-59.

9. Scollon EJ, Starr JM, Crofton KM, Wolansky MJ, DeVito MJ, Hughes MF. Correlation of tissue concentrations of the pyrethroid bifenthrin with neurotoxicity in the rat. Toxicology. 2011;290:1-6.

10. Shafer TJ, Meyer DA, Crofton KM. Developmental neurotoxicity of pyrethroid insecticides: critical review and future research needs. Environ Health Perspect. 2005:113:123-36.

11. Wolansky MJ, Harrill JA. Neurobehavioral toxicology of pyrethroid insecticides in adult animals: a critical review. Neurotoxicol Teratol. 2008;30:55-78.

12. Fetoui H, Feki A, Salah GB, Kamoun H, Fakhfakh F, Gdoura R. Exposure to lambda-cyhalothrin, a synthetic pyrethroid, increases reactive oxygen species production and induces genotoxicity in rat peripheral blood. Toxicol Ind Health. 2015:31:433-41.

13. Aouey B, Derbali M, Chtourou Y, Bouchard M, Khabir A, Fetoui H. Pyrethroid insecticide lambda-cyhalothrin and its metabolites induce liver injury through the activation of oxidative stress and proinflammatory gene expression in rats following acute and subchronic exposure. Environ Sci Pollut Res Int. 2017;24:5841-56.

14. Singh AK, Tiwari MN, Prakash O, Singh MP. A current review of Cypermethrin-induced neurotoxicity and nigrostriatal dopaminergic neurodegeneration. Curr Neuropharmacol. 2012;10:64-71.

15. Narahashi T, Ginsburg KS, Nagata K, Song JH, Tatebayashi H. Ion channels as targets for insecticides. Neurotoxicology. 1998;19:581-90

16. Bradberry SM, Thanacoody HKR, Watt BE, Thomas SHL, Vale JA. Management of the cardiovascular complications of tricyclic antidepressant poisoning: role of sodium bicarbonate. Toxicol Rev. 2005;24:195-204.

17. Breckenridge CB, Holden L, Sturgess N, Weiner M, Sheets L, Sargent D, et al. Evidence for a separate mechanism of toxicity for the type I and the type II pyrethroid insecticides. Neurotoxicology. 2009;30(1):S17-31. 
18. Zhang L, Gavin T, Barber DS, LoPachin RM. Role of the Nrf2-ARE pathway in acrylamide neurotoxicity. Toxicol Lett. 2011;205:1-7.

19. Zhao M, Lewis Wang FS, Hu X, Chen F, Chan HM. Acrylamide-induced neurotoxicity in primary astrocytes and microglia: roles of the Nrf2-ARE and NF-kB pathways. Food Chem Toxicol Int J Publ Br Ind Biol Res Assoc. 2017; 106:25-35

20. Li H, Wu S, Ma Q, Shi N. The pesticide deltamethrin increases free radical production and promotes nuclear translocation of the stress response transcription factor Nrf2 in rat brain. Toxicol Ind Health. 2011;27:579-90.

21. Baltazar MT, Dinis-Oliveira RJ, de Lourdes Bastos M, Tsatsakis AM, Duarte JA, Carvalho F. Pesticides exposure as etiological factors of Parkinson's disease and other neurodegenerative diseases_a mechanistic approach. Toxicol Lett. 2014:230:85-103.

22. Singh AK, Tiwari MN, Upadhyay G, Patel DK, Singh D, Prakash O, et al. Long term exposure to cypermethrin induces nigrostriatal dopaminergic neurodegeneration in adult rats: postnatal exposure enhances the susceptibility during adulthood. Neurobiol Aging. 2012;33:404-15.

23. Hossain MM, Richardson JR. Mechanism of pyrethroid pesticide-induced apoptosis: role of Calpain and the ER stress pathway. Toxicol Sci. 2011;122:512-25.

24. Ponomarev ED, Veremeyko T, Weiner HL. MicroRNAs are universal regulators of differentiation, activation and polarization of microglia and macrophages in normal and diseased CNS. Glia. 2013;61:91-103.

25. Koziorowski D, Tomasiuk R, Szlufik S, Friedman A. Inflammatory cytokines and NT-proCNP in Parkinson's disease patients. Cytokine. 2012;60:762-6.

26. Morales R, Estrada LD, Diaz-Espinoza R, Morales-Scheihing D, Jara MC, Castilla J, et al. Molecular cross talk between misfolded proteins in animal models of Alzheimer's and prion diseases. J Neurosci. 2010;30:4528-35.

27. Rubio-Perez JM, Morillas-Ruiz JM. A review: inflammatory process in Alzheimer's disease, role of cytokines. ScientificWorldJournal. 2012;2012:756357.

28. Venegas C, Kumar S, Franklin BS, Dierkes T, Brinkschulte R, Tejera D, et al. Microglia-derived ASC specks cross-seed amyloid- $\beta$ in Alzheimer's disease. Nature. 2017:552:355-61.

29. Spangenberg EE, Green KN. Inflammation in Alzheimer's disease: lessons learned from microglia-depletion models. Brain Behav Immun. 2017;61:1-11.

30. di Penta A, Moreno B, Reix S, Fernandez-Diez B, Villanueva M, Errea O, et al. Oxidative stress and proinflammatory cytokines contribute to demyelination and axonal damage in a cerebellar culture model of neuroinflammation. PLoS One. 2013:8:e54722.

31. Vinet J, Weering HRJ, van Heinrich A, Kälin RE, Wegner A, Brouwer N, et al. Neuroprotective function for ramified microglia in hippocampal excitotoxicity. J Neuroinflammation. 2012;9:27.

32. Kauppinen TM, Higashi Y, Suh SW, Escartin C, Nagasawa K, Swanson RA. Zinc triggers microglial activation. J Neurosci. 2008;28:5827-35.

33. Mou YH, Yang JY, Cui N, Wang JM, Hou Y, Song S, et al. Effects of cobalt chloride on nitric oxide and cytokines/chemokines production in microglia. Int Immunopharmacol. 2012;13:120-5.

34. Lehnardt S. Innate immunity and neuroinflammation in the CNS: the role of microglia in Toll-like receptor-mediated neuronal injury. Glia. 2010;58:253-63.

35. Rosenberger K, Derkow K, Dembny P, Krüger C, Schott E, Lehnardt S. The impact of single and pairwise Toll-like receptor activation on neuroinflammation and neurodegeneration. J Neuroinflammation. 2014;11:166.

36. Jazwa A, Cuadrado A. Targeting heme oxygenase-1 for neuroprotection and neuroinflammation in neurodegenerative diseases. Curr Drug Targets. 2010;11:1517-31.

37. Innamorato NG, Jazwa A, Rojo Al, García C, Fernández-Ruiz J, GrochotPrzeczek A, et al. Different susceptibility to the Parkinson's toxin MPTP in mice lacking the redox master regulator Nrf2 or its target gene heme oxygenase-1. PLoS One. 2010;5:e11838.

38. Yoh K, Hirayama A, Ishizaki K, Yamada A, Takeuchi M, Yamagishi S, et al. Hyperglycemia induces oxidative and nitrosative stress and increases renal functional impairment in Nrf2-deficient mice. Genes Cells Devoted Mol Cell Mech. 2008:13:1159-70.

39. Thimmulappa RK, Scollick C, Traore K, Yates M, Trush MA, Liby KT, et al. Nrf2dependent protection from LPS induced inflammatory response and mortality by CDDO-Imidazolide. Biochem Biophys Res Commun. 2006;351:883-9.

40. Ross G, Hübschle T, Pehl U, Braun H-A, Voigt K, Gerstberger R, et al. Fever induction by localized subcutaneous inflammation in guinea pigs: the role of cytokines and prostaglandins. J Appl Physiol Bethesda Md 1985. 2003:94:1395-402.

41. Mancino A, Lawrence T. Nuclear factor-kappaB and tumor-associated macrophages. Clin Cancer Res Off J Am Assoc Cancer Res 2010;16:784-789.
42. Romero A, Ares I, Ramos E, Castellano V, Martínez M, Martínez-Larrañaga $M R$, et al. Evidence for dose-additive effects of a type II pyrethroid mixture. In vitro assessment. Environ Res. 2015;138:58-66.

43. Bhatia HS, Roelofs N, Muñoz E, Fiebich BL. Alleviation of microglial activation induced by p38 MAPK/MK2/PGE2 axis by capsaicin: potential involvement of other than TRPV1 mechanism/s. Sci Rep [Internet]. 2017 [cited 2018 Jan 14];7. Available from: http://www.nature.com/articles/ s41598-017-00225-5

44. Yousif NM, de Oliveira ACP, Brioschi S, Huell M, Biber K, Fiebich BL. Activation of $E P_{2}$ receptor suppresses poly(l: C) and LPS-mediated inflammation in primary microglia and organotypic hippocampal slice cultures: contributing role for MAPKs. Glia [Internet]. 2017 [cited 2018 Jan 14]; Available from: http://doi.wiley.com/10.1002/glia.23276

45. Denizot F, Lang R. Rapid colorimetric assay for cell growth and survival. Modifications to the tetrazolium dye procedure giving improved sensitivity and reliability. J Immunol Methods. 1986;89:271-7.

46. Green LC, Wagner DA, Glogowski J, Skipper PL, Wishnok JS, Tannenbaum SR. Analysis of nitrate, nitrite, and [15N]nitrate in biological fluids. Anal Biochem. 1982;126:131-8.

47. Ou P, Wolff SP. A discontinuous method for catalase determination at "near physiological" concentrations of $\mathrm{H} 2 \mathrm{O} 2$ and its application to the study of H2O2 fluxes within cells. J Biochem Biophys Methods. 1996;31:59-67.

48. Draper $\mathrm{HH}$, Hadley M. Malondialdehyde determination as index of lipid peroxidation. Methods Enzymol. 1990;186:421-31.

49. Aebi H. Catalase in vitro. Methods Enzymol. 1984;105:121-6.

50. Marklund S, Marklund G. Involvement of the superoxide anion radical in the autoxidation of pyrogallol and a convenient assay for superoxide dismutase. Eur J Biochem. 1974:47:469-74.

51. Flohé L, Günzler WA. Assays of glutathione peroxidase. Methods Enzymol. 1984:105:114-21.

52. Livak KJ, Schmittgen TD. Analysis of relative gene expression data using real-time quantitative PCR and the 2(-delta delta $C(T)$ ) method. Methods San Diego Calif. 2001;25:402-8.

53. Stoppini L, Buchs PA, Muller D. A simple method for organotypic cultures of nervous tissue. J Neurosci Methods. 1991;37:173-82.

54. Masuch A, Shieh C-H, van Rooijen N, van Calker D, Biber K. Mechanism of microglia neuroprotection: involvement of P2X7, TNFa, and valproic acid. Glia. 2016:64:76-89.

55. Shieh C-H, Heinrich A, Serchov T, van Calker D, Biber K. P2X7-dependent, but differentially regulated release of IL-6, CCL2, and TNF-a in cultured mouse microglia. Glia. 2014;62:592-607.

56. Wardyn JD, Ponsford AH, Sanderson CM. Dissecting molecular cross-talk between Nrf2 and NF-kB response pathways. Biochem Soc Trans. 2015;43:621-6.

57. Eaton DL, Daroff RB, Autrup H, Bridges J, Buffler P, Costa LG, et al. Review of the toxicology of chlorpyrifos with an emphasis on human exposure and neurodevelopment. Crit Rev Toxicol. 2008;38(2):1-125.

58. Taetzsch T, Block ML. Pesticides, microglial NOX2, and Parkinson's disease. J Biochem Mol Toxicol. 2013;27:137-49.

59. Lahouel A, Kebieche M, Lakroun Z, Rouabhi R, Fetoui H, Chtourou Y, et al. Neurobehavioral deficits and brain oxidative stress induced by chronic low dose exposure of persistent organic pollutants mixture in adult female rat. Environ Sci Pollut Res Int. 2016;23:19030-40.

60. Paul KC, Sinsheimer JS, Rhodes SL, Cockburn M, Bronstein J, Ritz B. Organophosphate pesticide exposures, nitric oxide synthase gene variants, and gene-pesticide interactions in a case-control study of Parkinson's disease, California. Environ Health Perspect [Internet]. 2015 [cited 2018 14]; 124. Available from: http://ehp.niehs.nih.gov/1408976

61. Hossain MM, Liu J, Richardson JR. Pyrethroid insecticides directly activate microglia through interaction with voltage-gated sodium channels. Toxicol Sci. 2017:155:112-23.

62. Romero A, Ramos E, Castellano V, Martínez MA, Ares I, Martínez M, et al. Cytotoxicity induced by deltamethrin and its metabolites in SH-SY5Y cells can be differentially prevented by selected antioxidants. Toxicol Vitro Int J Publ Assoc BIBRA. 2012:26:823-30.

63. Heneka MT, Kummer MP, Latz E. Innate immune activation in neurodegenerative disease. Nat Rev Immunol. 2014;14:463-77.

64. Blank T, Prinz M. Type I interferon pathway in CNS homeostasis and neurological disorders. Glia. 2017:65:1397-406.

65. Rice RA, Pham J, Lee RJ, Najafi AR, West BL, Green KN. Microglial repopulation resolves inflammation and promotes brain recovery after injury. Glia. 2017;65:931-44. 
66. Mumaw CL, Surace M, Levesque S, Kodavanti UP, Kodavanti PRS, Royland JE, et al. Atypical microglial response to biodiesel exhaust in healthy and hypertensive rats. Neurotoxicology. 2017;59:155-63.

67. Zhang W, Yan Z, Gao J, Sun L, Huang X, Liu Z, et al. Role and mechanism of microglial activation in iron-induced selective and progressive dopaminergic neurodegeneration. Mol Neurobiol. 2014:49:1153-65.

68. Taupin P. A dual activity of ROS and oxidative stress on adult neurogenesis and Alzheimer's disease. Cent Nerv Syst Agents Med Chem. 2010;10:16-21.

69. Zorov DB, Juhaszova M, Sollott SJ. Mitochondrial reactive oxygen species (ROS) and ROS-induced ROS release. Physiol Rev. 2014;94:909-50.

70. Liu H, Xu L, Zhao M, Liu W, Zhang C, Zhou S. Enantiomer-specific, bifenthrin-induced apoptosis mediated by MAPK signalling pathway in Hep G2 cells. Toxicology. 2009;261:119-25.

71. Nita M, Grzybowski A. The role of the reactive oxygen species and oxidative stress in the pathomechanism of the age-related ocular diseases and other pathologies of the anterior and posterior eye segments in adults. Oxidative Med Cell Longev. 2016;2016:3164734.

72. Narra MR, Rajender K, Reddy RR, Murty US, Begum G. Insecticides induced stress response and recuperation in fish: biomarkers in blood and tissues related to oxidative damage. Chemosphere. 2017;168:350-7.

73. El-Demerdash FM. Lipid peroxidation, oxidative stress and acetylcholinesterase in rat brain exposed to organophosphate and pyrethroid insecticides. Food Chem Toxicol. 2011;49:1346-52.

74. Zhou H, Yuan Y, Qi Z, Tong Q, Zhang K. Study on changes of plasma levels of oxidative stress biomarkers and its relation with cognition function in patients with parkinson's disease. Zhonghua Yi Xue Za Zhi. 2015;95:3357-60.

75. Hu F, Li L, Wang C, Zhang Q, Zhang X, Zhao M. Enantioselective induction of oxidative stress by permethrin in rat adrenal pheochromocytoma (PC12) cells. Environ Toxicol Chem. 2010;29:683-90.

76. Choi SH, Lee DY, Kim SU, Jin BK. Thrombin-induced oxidative stress contributes to the death of hippocampal neurons in vivo: role of microglial NADPH oxidase. J Neurosci. 2005;25:4082-90.

77. Kraft AD, Harry GJ. Features of microglia and neuroinflammation relevant to environmental exposure and neurotoxicity. Int J Environ Res Public Health. 2011;8:2980-3018.

78. Spielman LJ, Gibson DL, Klegeris A. Incretin hormones regulate microglia oxidative stress, survival and expression of trophic factors. Eur J Cell Biol. 2017:96:240-53

79. Buendia I, Michalska P, Navarro E, Gameiro I, Egea J, León R. Nrf2-ARE pathway: an emerging target against oxidative stress and neuroinflammation in neurodegenerative diseases. Pharmacol Ther. 2016;157:84-104.

80. Ahmed SMU, Luo L, Namani A, Wang XJ, Tang X. Nrf2 signaling pathway: pivotal roles in inflammation. Biochim Biophys Acta (BBA) - Mol Basis Dis. 1863;2017:585-97.

81. Li H, Wang P, Huang F, Jin J, Wu H, Zhang B, et al. Astragaloside IV protects blood-brain barrier integrity from LPS-induced disruption via activating Nrf2 antioxidant signaling pathway in mice. Toxicol Appl Pharmacol. 2018;340:58-66.

82. Tebay LE, Robertson H, Durant ST, Vitale SR, Penning TM, Dinkova-Kostova AT, et al. Mechanisms of activation of the transcription factor Nrf2 by redox stressors, nutrient cues, and energy status and the pathways through which it attenuates degenerative disease. Free Radic Biol Med. 2015;88:108-46.

83. Shang Y, Zhou Q, Wang T, Jiang Y, Zhong Y, Qian G, et al. Airborne nitroPAHs induce Nrf2/ARE defense system against oxidative stress and promote inflammatory process by activating PI3K/Akt pathway in A549 cells. Toxicol Vitro Int J Publ Assoc BIBRA. 2017:44:66-73.

84. Li HY, Wu S-Y, Shi N. Transcription factor Nrf2 activation by deltamethrin in PC12 cells: involvement of ROS. Toxicol Lett. 2007;171:87-98.

85. Dröge W, Schipper HM. Oxidative stress and aberrant signaling in aging and cognitive decline. Aging Cell. 2007;6:361-70

86. Attoff K, Kertika D, Lundqvist J, Oredsson S, Forsby A. Acrylamide affects proliferation and differentiation of the neural progenitor cell line C17.2 and the neuroblastoma cell line SH-SY5Y. Toxicol Vitro Int J Publ Assoc BIBRA. 2016;35:100-11.

87. Dansokho C, Heneka MT. Neuroinflammatory responses in Alzheimer's disease. J Neural Transm Vienna Austria 1996. 2018;125:771-9.

88. Juckel G, Manitz MP, Brüne M, Friebe A, Heneka MT, Wolf RJ. Microglial activation in a neuroinflammational animal model of schizophrenia-a pilot study. Schizophr Res. 2011;131:96-100.
89. Smith JA, Das A, Ray SK, Banik NL. Role of pro-inflammatory cytokines released from microglia in neurodegenerative diseases. Brain Res Bull. 2012;87:10-20.

90. Perez Nievas BG, Hammerschmidt T, Kummer MP, Terwel D, Leza JC, Heneka MT. Restraint stress increases neuroinflammation independently of amyloid $\beta$ levels in amyloid precursor protein/PS1 transgenic mice. J Neurochem. 2011;116:43-52.

91. Sadasivan S, Pond BB, Pani AK, Qu C, Jiao Y, Smeyne RJ. Methylphenidate exposure induces dopamine neuron loss and activation of microglia in the basal ganglia of mice. PLoS One. 2012;7:e33693.

92. Kierdorf K, Prinz M. Factors regulating microglia activation. Front Cell Neurosci. 2013;7:44.

93. Hellwig S, Heinrich A, Biber K. The brain's best friend: microglial neurotoxicity revisited. Front Cell Neurosci. 2013;7:71.

94. Fiebich BL, Akter S, Akundi RS. The two-hit hypothesis for neuroinflammation: role of exogenous ATP in modulating inflammation in the brain. Front Cell Neurosci. 2014;8:260.

95. Spangenberg EE, Lee RJ, Najafi AR, Rice RA, Elmore MRP, Blurton-Jones M, et al. Eliminating microglia in Alzheimer's mice prevents neuronal loss without modulating amyloid- $\beta$ pathology. Brain J Neurol. 2016;139:1265-81.

96. Rice RA, Spangenberg EE, Yamate-Morgan H, Lee RJ, Arora RPS, Hernandez $M X$, et al. Elimination of microglia improves functional outcomes following extensive neuronal loss in the hippocampus. J Neurosci. 2015;35:9977-89.

97. Shemer A, Erny D, Jung S, Prinz M. Microglia plasticity during health and disease: an immunological perspective. Trends Immunol. 2015;36:614-24.

98. Blank T, Prinz M. NF-kB signaling regulates myelination in the CNS. Front Mol Neurosci. 2014;7:47.

99. Raasch J, Zeller N, van Loo G, Merkler D, Mildner A, Erny D, et al. IkappaB kinase 2 determines oligodendrocyte loss by non-cell-autonomous activation of NF-kappaB in the central nervous system. Brain J Neurol. 2011;134:1184-98.

100. de Oliveira ACP, Yousif NM, Bhatia HS, Hermanek J, Huell M, Fiebich BL. Poly $(1: C)$ increases the expression of mPGES-1 and COX-2 in rat primary microglia. J Neuroinflammation. 2016;13:11.

101. Bhatia HS, Baron J, Hagl S, Eckert GP, Fiebich BL. Rice bran derivatives alleviate microglia activation: possible involvement of MAPK pathway. J Neuroinflammation. 2016:13:148.

102. Kim SF, Huri DA, Snyder SH. Inducible nitric oxide synthase binds, Snitrosylates, and activates cyclooxygenase-2. Science. 2005;310:1966-70.

103. Cuadrado A, Martín-Moldes Z, Ye J, Lastres-Becker I. Transcription factors NRF2 and NF-KB are coordinated effectors of the Rho family, GTP-binding protein RAC1 during inflammation. J Biol Chem. 2014;289:15244-58.

104. Taetzsch T, Levesque S, McGraw C, Brookins S, Luqa R, Bonini MG, et al. Redox regulation of NF-KB p50 and M1 polarization in microglia. Glia. 2015;63:423-40

105. Lee PC, Raaschou-Nielsen O, Lill CM, Bertram L, Sinsheimer JS, Hansen J, et al. Gene-environment interactions linking air pollution and inflammation in Parkinson's disease. Environ Res. 2016;151:713-20.

106. Brigelius-Flohé R, Flohé L. Basic principles and emerging concepts in the redox control of transcription factors. Antioxid Redox Signal. 2011;15:2335-81.

107. Bellezza I, Mierla AL, Minelli A. Nrf2 and NF-KB and their concerted modulation in cancer pathogenesis and progression. Cancers. 2010;2:483-97.

108. Minelli A, Conte C, Grottelli S, Bellezza I, Cacciatore I, Bolaños JP. Cyclo (His-pro) promotes cytoprotection by activating Nrf2-mediated up-regulation of antioxidant defence. J Cell Mol Med. 2009;13:1149-61.

109. Lutz JA, Carter M, Fields L, Barron S, Littleton JM. Altered relation between lipopolysaccharide-induced inflammatory response and excitotoxicity in rat organotypic hippocampal slice cultures during ethanol withdrawal. Alcohol Clin Exp Res. 2015:39:827-35.

110. Järvelä JT, Ruohonen S, Kukko-Lukjanov T-K, Plysjuk A, Lopez Picon FR, Holopainen IE. Kainic acid-induced neurodegeneration and activation of inflammatory processes in organotypic hippocampal slice cultures: treatment with cyclooxygenase-2 inhibitor does not prevent neuronal death. Neuropharmacology. 2011;60:1116-25. 